\title{
5. Sınıf İngilizce Dersi Öğretim Programı: Güncellenen Programın Bir Önceki Programla Karşılaştırılması ve Programa İlişkin Öğretmen Görüşleri*
}

$$
\text { Zeynep DEMIRTAŞ** }
$$

\author{
Serdar ERDEM ${ }^{* * *}$
}

Öz

Araştırmanın amacı, 2013-2014 öğretim yılında uygulanmaya başlayan yeni 5. sınıf İngilizce dersi öğretim programı ile 2008-2009 öğretim yılında başlayarak uygulanmış olan 5. sınıf İngilizce dersi öğretim programının karşılaştırılmalı olarak incelenmesi ve yeni programa ilişkin öğretmenlerin görüşlerinin belirlenmesidir. Araştırma iki aşamadan oluşmaktadır. Birinci aşamada 2013'de yürürlüğe giren 5. sınıf İngilizce dersi öğretim programı ile 2006'da geliştirilen ve 2008'den itibaren okutulmakta olan 5. sınıf İngilizce dersi öğretim programı karşılaştırılmıştır. Bu aşamada nitel araştırma yöntemlerinden doküman analizi yöntemi kullanılmıştır. Araştırmanın İkinci aşamasında 2013 programına ilişkin İngilizce öğretmenlerinin görüşleri belirlenmiştir. Bu aşamada nitel araştırma yöntemlerinden görüşme yöntemi kullanılmış ve yarı yapılandırılmış görüşme sorularıyla öğretmenlerin görüşleri belirlenmiştir. Amaçlı örnekleme yöntemi kullanılan araştırmada, İstanbul ili Sultanbeyli ilçesinde Milli Eğitim Bakanlığına bağlı okullarda görev yapmakta olan 19 İngilizce öğretmeni ile 2013-2014 öğretim yılı ikinci dönemde görüşmeler yapılmıştır. Elde edilen veriler betimsel analiz yöntemiyle çözümlenmiştir. Araştırmanın sonucunda bir önceki programdan farklı olarak yeni programda yapılan yenilikler ortaya konulmuş ve öğretmenlerin yeni programa ilişkin genellikle olumsuz görüşlere sahip olduğu belirlenmiştir.

Anahtar Kelimeler: İngilizce dersi öğretim programı, İngilizce öğretimi, öğretmen görüşleri.

\section{Fifth Grade English Course Curriculum: Comparison of The Revised Curriculum With The Previous Curriculum and Teachers' Views Related to The New Curriculum}

\begin{abstract}
The aim of this research is to investigate comparatively English language curriculum of the fifth grade which started to be applied in 2013-2014 academic year and the English language curriculum of the fifth grade applied since 2008-2009 academic year and to determine teachers' views about new curriculum. The research consists of two stages. At the first stage, the English language curri-
\end{abstract}

\footnotetext{
* Bu çalışmanın özeti 7-9 Mayıs 2014 tarihinde Gaziantep Üniversitesi'nde gerçekleştirilen III. Ulusal Eğitim Programları ve Öğretim Sempozyumu'nda sunulmuştur.

** Yrd. Doç. Dr., Sakarya Üniversitesi, zeynept@sakarya.edu.tr

${ }^{* * *}$ Sakarya Üniversitesi, Eğitim Fakültesi, Eğitim Bilimleri Bölümü, serdarerdem90@gmail.com
} 
culum of the fifth grade, effectuated in 2013, was compared with the English language curriculum of the fifth grade, developed in 2006 and valid starting from 2008. At this stage, document analysis method of the qualitative research methods was used. At the second stage of the research, teachers' views about 2013 curriculum were determined. At this stage, the interview method of the qualitative research methods was used and teachers' views were determined with semi-structured interview questions. In this research, in which purposeful sampling was used, interviews were made with 19 English teachers working at the state schools in Sultanbeyli/Istanbul at the second term of 2013-2014 academic year. The data obtained from these interviews were analysed using descriptive analysis method. At the end of the research, the innovations made in the new curriculum, unlike the previous curriculum, were revealed and it was determined that teachers had generally negative opinions about new curriculum.

Keywords: English course curriculum, teaching english, teachers' views.

\section{Gíriş}

Küreselleşen dünyada, uluslararası iletişimi ve etkileşimi sağlamak amacıyla yabancı dil eğitimi önem kazanmış ve ayrıca bireylerin gerek akademik gelişimleri, gerek kişisel gelişimleri açısından da yabancı dil eğitimi bir zorunluluk haline gelmiştir (Büyükyavuz ve Aydoslu, 2005). Artan bu önemle birlikte, "neden yabanc1 dil öğreniyoruz? ve neden yabancı dil öğretiyoruz?" sorularına cevaplar aranmaya başlanmıştır. İlkhan'a (1999) göre yabancı dil öğrenmenin nedeni içinde yaşadığımız toplumun ekonomik, sosyal ve kültürel kalkınmasını gerçekleştirmektir. Songün'e (1983) göre gelişmekte olan ülkemizin kültürü içinde çok önemli bir yere sahip olan yabancı dilin öğretimi ile toplumu ileriye taşıyacak daha çağdaş düşünceli bireyler yetiştirmek mümkün olacaktır.

Her geçen gün yabancı dil öğrenmeye olan istek giderek artmaktadır. Özellikle son yıllarda devlet kurumlarında ve özel kurumlarda İngilizce dersi, hem öğrenciler hem de veliler tarafından çok önem verilen dersler arasına girmiştir. Geçmişten günümüze eğitim sistemindeki değişiklikler ile birlikte İngilizce eğitiminde de yenilikler yapılmıştır. 1997-1998 eğitim-öğretim yılından itibaren yabancı dil dersi ilköğretim okullarının dördüncü sınıfından başlamak üzere zorunlu hale getirilmiştir. 2006'da hazırlanan İngilizce dersi öğretim programı ile birlikte İngilizce öğretimi daha çă̆daş temeller üzerine inşa edilmeye çalışılmıştır. 2012 yılında $4+4+4$ eğitim sistemi ile birlikte yapılan değişikliklerle, İngilizce dersleri ilkokul 2. sınıftan itibaren başlamaktadır. Yabancı dil eğitiminde ortaya çıkan çağdaş yaklaşım ve tekniklere paralel olarak 2013 yılında İngilizce dersi öğretim programı güncellenmiştir. İngiliz dili eğitimi alanında yapılan bütün çalışmalara ve yeniliklere rağmen ne temel eğitimde, ne ortaöğretimde, ne de yükseköğretimde yabancı dil öğrenmede istenilen sonuçlara ulaşılamamaktadır. Dil öğretiminde karşılaşılan güçlükler geçmişte olduğu gibi günümüzde de güncelliğini korumakta ve dil öğretimiyle ilgili çeşitli sorunlar yaşanmaktadır (İşeri, t.y.). Yabancı dil öğretimindeki bu verimsizliğin nedenleri; geleneksel dil öğrenme alışkanlıkları, yabancı dil eğitimi programlarındaki eksiklikler ve uygulamada gerçekleştirilen yöntem, etkinlik, malzeme ve ölçme değerlendirmedeki aksaklıklar ve yanlışlıklar olarak gösterilmektedir (Işık, 2008). Ülkemizde yabancı dil öğrenme başarısını olumsuz etkileyen bu unsurlar arasında programların önemini ayrıca vurgulamak gerekir. Öğretim programları ile derslerin öğretim sürecindeki uygulamalar bir bütün olarak görülebilir. Çünkü öğretim programları öğretmenlerin derslerde öğrenme öğretme etkinliklerini hangi çerçeve planına göre sürdüreceğini ve nasıl bir değerlendirme yaklaşımını kullanabileceğine rehberlik etmektedir. Öğretim programının bu işlevi 
dikkate alındığında, ülkemizde yabancı dili etkin ve doğru kullanabilecek öğrencileri yetiştirecek nitelikte programların hazırlanması önemlidir. Richards (2001) bu konuda ortama özgün yabancı dil programı geliştirmenin önemini vurgulamaktadır. Yabancı dil öğrenmeyi toplumdan ve kültürden ayrı düşünmek doğru değildir. Program geliştirme sürecinde uygulanmak da olan programdaki eksikliklerin farkına varılması ve yeni hazırlanan programda bu eksikliklerin giderilmesi gerekmektedir. Öncelikle uygulanan yanlış yöntemlerden vazgeçilmelidir. Dil, bilgi aktarımını sağlayan bir iletişim aracı olduğu için yabancı dili öğrenmek için o dil ile iletişimi sağlayacak zengin girdi sağlanmalıdır (Işık, 2008). Çünkü yabancı dil eğitiminde anlama konusu göz ardı edilip, dilin öğelerini öğretmeyi amaçlayan çalışmalardan dolayı verim alınamamaktadır (Krashen, 2003). Ellis (1990) de bir dilin konuşulabilmesi için dille ilgili dilbilgisi kurallarının çok iyi bilinmesine ihtiyaç olunmadığını ifade etmektedir. Milli Eğitim Bakanlığı tarafından yürütülen çalışmalar sonucu hazırlanan programlarda her ne kadar sadece dilbilgisine odaklanılmadığını, okuma, dinleme, yazma ve konuşma becerilerine eşit ağırlıkla yer verildiği ifade edilse de gerçekteki durum bundan çok farklıdır (Paker, 2006). Yeni hazırlanan programlarda dilbilgisi kurallarından ziyade iletişime odaklanılmakta ve ders materyalleri ile dilin kullanıldığı bağlamlar daha çok gerçek hayattan seçilmeye çalışılmaktadır. Fakat yine de gerek eğitim-öğretim ortamından gerekse metodolojiden kaynaklanan sorunlar nedeniyle yabancı dil öğretimi ile beklentilerin karşılanamadığı düşünülmektedir. Bu doğrultuda, araştırmada bireylere daha verimli ve daha etkili bir İngilizce öğretimi için güncellenen İngilizce dersi öğretim programının bir önceki programla karşılaştırılması ve güncellenen programın öğretmenlerin görüşlerine göre incelenmesi planlanmıştır. Programda yapılan değişikliklerin belirlenmesi, öğretim programının İngilizce öğretimi ile ilgili belirtilen ihtiyaçları karşılayıp karşılayamadığının sorgulanması açısından önemli görülmektedir. Ayrıca, programın uygulayıcıları olan öğretmenlerin programla ilgili görüşlerinin belirlenmesi ve uygulamada karşılaşılan sorunların ilk elden betimlenmesi ile İngilizce öğretiminde yaşanan sorunlara gerçekçi çözümlerin getirilmesi ve daha etkili öğrenme yaşantıları sağlamaya katkıda bulunması açısından önemli olduğu düşünülmektedir.

\subsection{Amaç}

Araştırmanın amacı, 2013-2014 öğretim yılında uygulanmaya başlayan yeni 5. sınıf İngilizce dersi öğretim programı ile 2008-2009 öğretim yılından itibaren uygulanmış olan 5. sınıf İngilizce dersi öğretim programının karşılaştırılmalı olarak incelenmesi ve yeni programa ilişkin öğretmenlerin görüşlerinin belirlenmesidir.

\section{YÖNTEM}

Araştırma iki aşamadan oluşmaktadır. Birinci aşamada 2013' de yürürlüğe giren 5. sınıf İngilizce dersi öğretim programı ile 2006' da geliştirilen ve 2008'den itibaren okutulmakta olan 5 . sınıf İngilizce dersi öğretim programı karşılaştırılmıştır. Yeni program “2013 programı” olarak, bir önceki programda "2006 programı" şeklinde ifade edilmiş ve her iki programın ortak yönleri ile farklı yönleri ortaya koyularak tartışılmıştır. Bu aşamada nitel araştırma yöntemlerinden doküman analizi yöntemi kullanılmış ve ilgili dokümanlar Milli Eğitim Bakanlığı Talim ve Terbiye Kurulu resmi internet sitesinde yayınlanan 5. sinıf İngilizce dersi öğretim programları (2006 programı ve 2013 programı) incelenmiştir. Araştırmanın İkinci aşamasında 2013 programına ilişkin İngilizce 
öğretmenlerinin görüşleri belirlenmiştir. Bu aşamada nitel araştırma yöntemlerinden görüşme yöntemi kullanılmış ve yarı yapılandırılmış görüşme sorularıyla öğretmenlerin görüşleri belirlenmiştir. Amaçlı örnekleme yöntemi kullanılan araştırmada, İstanbul ili Sultanbeyli ilçesinde Milli Eğitim Bakanlığına bağlı okullarda görev yapmakta olan 15 bayan, 4 erkek toplam 19 İngilizce öğretmeni ile 20132014 öğretim yılı ikinci dönemde görüşmeler yapılmıştır. Görüşme yapılan öğretmenlerden 16 tanesi fakültelerin İngilizce Öğretmenliği ve İngiliz Dili ve Edebiyatı bölümlerinden mezun kadrolu İngilizce öğretmeni iken; 3 tanesi de farklı fakültelerden mezun olan ücretli İngilizce öğretmenidir. Kadrolu olarak görev yapan öğretmenlerden 9 İngilizce öğretmeni 6-10 yıl arası kıdeme sahipken, 5 öğretmen 3-5 yıl arası kıdeme sahiptir. 1 öğretmen ise aday öğretmen statüsünde görevinde birinci yllına devam etmektedir. Yarı yapılandırılmış görüşme formunda, öğretmenlerin yeni programa ilişkin genel görüşleri, yeni programla ilgili tanıtım/bilgilendirme yapılma durumu, programda yer alan öğrencilerde geliştirilmesi hedeflenen becerilerle, öğrenme-öğretme sürecinde uygulanması öngörülen temel aktiviteler/stratejilerle ve değerlendirme yöntemleriyle, programın uygulanmasında yaşanılan sıkıntılar/problemler ve bunlara yönelik kendi çözüm önerileriyle ilgili öğretmenlerin görüşlerini belirleyen sorular yer almaktadır. Elde edilen veriler betimsel analiz yöntemiyle çözümlenerek tablolar şeklinde sunulmuştur.

\section{BULGULAR}

2006 “İngilizce dersi öğretim programı" ile 2013 "İngilizce dersi öğretim programı",bir bütün olarak programın genel yapıs1,5. sınıf programının amaçları, temel yaklaşımı, öğretim yöntem ve teknikleri, ölçme ve değerlendirme anlayışı, ana dil kullanımı, üniteler, kazanımlar ve beceriler alt başlıkları altında karşılaştırılarak incelenmiştir.

\subsection{Programın Genel Yapısı}

4+4+4 eğitim sistemine geçişle birlikte pek çok disiplin alanında olduğu gibi İngilizce dersi öğretim programında da değişiklikler yapılmıştır. Yapılan bu değişikliklerle, ülkemizde uzun yıllardır bir sorun olan yabancı dil öğretiminin başarıya ulaşması hedeflenmiş, yetişen öğrencilerin İngilizce iletişim kurabilen, okuduğunu ve dinlediğini anlayabilen bireyler haline gelmesi amaçlanmıştır. Programda yapılan değişiklikler kapsamında 5. sınıf programı incelendiğinde, öncelikle İngilizce öğrenme yaşının düşürüldüğü göze çarpmaktadır. 2006 İngilizce dersi öğretim programında İngilizce, Milli Eğitim Bakanlığı bünyesindeki devlet okullarında 4 . sinıfta ilk defa ders olarak yer alırken, 2013 programinda İngilizce derslerinin 2. sinıfta başladığı görülmektedir.

Tablo 1. İngilizce Dersinin Öğretim Programında Yer Aldığı Sınıflar

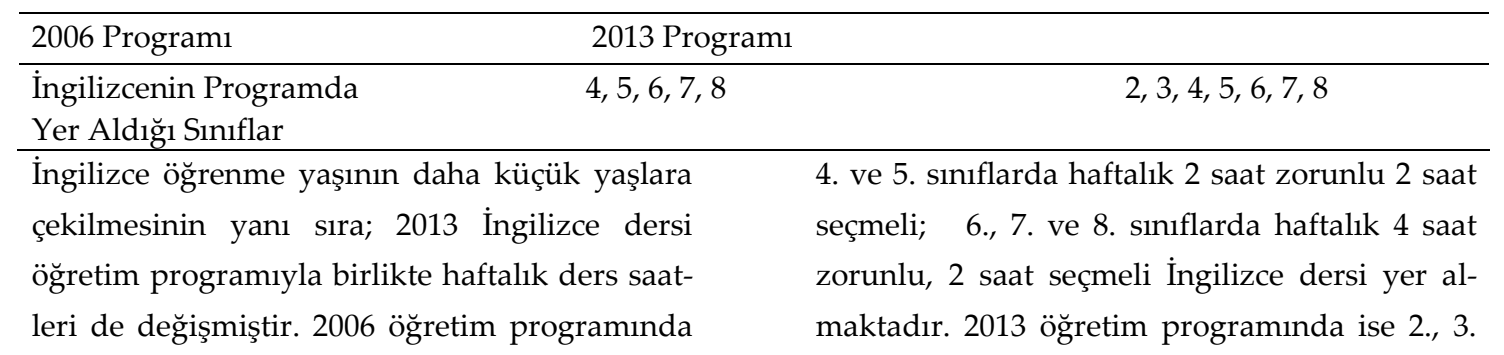


ve 4. sinıf seviyesinde haftalık 2 saat zorunlu, 5 . ve 6. siniflarda haftalık 3 saat zorunlu, 2 saat seçmeli, 7. ve 8. sınıflarda haftalık 4 saat zorunlu, 2 saat seçmeli İngilizce dersi yer almaktadır.

Tablo 2. Programların Haftalık Ders Saatleri

\begin{tabular}{llcc}
\hline & & 2006 Programi & 2013 Programi \\
\hline & 2. sinif & & 2 \\
Haftalik Ders & 3. sinif & & 2 \\
Saatleri & 4. sinif & $2(+2)^{*}$ & 2 \\
& 5. sinif & $2(+2)^{*}$ & $3(+2)^{*}$ \\
& 6. sinif & $4(+2)^{*}$ & $3(+2)^{*}$ \\
& 7. sinif & $4(+2)^{*}$ & $4(+2)^{*}$ \\
\hline
\end{tabular}

* Seçmeli İngilizce ders saatleri

\subsection{Programın Amaçları}

Her iki programın genel amaçları iletişime dayalı olması açısından birbiriyle benzerlik gösterse de 2013 programinda genel amacın tanımı daha geniştir. 2006 5. sınıf İngilizce dersi öğretim programının genel amacı, öğrencilerin İngilizceyi doğru ve uygun şekilde kullanması iken, 2013 programının genel amacı, dili öğrenenlerin İngilizce öğrenmeye olan ilgilerini arttırmak ve bu dili gerçek yaşamda kullanabilmelerini sağlamaktır. Diğer bir deyişle her iki programda da genel hedef iletişimi sağlamaktır. Fakat 2013 programı iletişimi sağlamak ve dili etkili kullanmak için ilginin uyandırılmasının da bir amaç olması gerektiğini vurgulamıştır. Genel amaçların yanı sıra 2006 programında, öğrencilerin kişisel bilgi ve ihtiyaçlarını ifade etmeleri, temel kelime bilgisine sahip olmaları, birkaç basit dilbilgisi kuralını ve cümle yapısını kullanmaları, öğrenilmiş sınırlı sa- yıdaki kelimeleri doğru telaffuz etmeleri, sık karşılaşılan ifadeleri kullanmaları ve taklit etmeleri, öğrendikleri ifadeleri doğru olarak yazmaları, selamlaşma, teşekkür etme, vedalaşma gibi günlük dilde basit iletişim kurmaları amaçlanmıştır. 2013 programında ise öğrencilerin ilgi, istek, duygu, alışkanlık ve rahatsızlıklarını karşılarındakinin anlayacağı şekilde ifade etmeleri, selamlaşma ve izin istemeleri, kişisel düşüncelerini, beğenilerini ve ihtiyaçlarını belirtmeleri, saat sorma ve yol tarifi gibi günlük dilde ihtiyacını duyacağı ifadeleri kullanmaları, temel dil işlevlerini yerine getirmeleri, yeteneklerini ve zorunlu olduğu şeyleri ifade etmeleri ve olay anında yaşadıklarını anlatmaları hedeflenmektedir. Her iki programın da benzer iletişimsel kazanımlara sahip olduğu söylenebilir.

Tablo 3. Programların Genel Amaçları

\begin{tabular}{|c|c|c|c|}
\hline & & 2006 Programı & 2013 Programı \\
\hline & Genel Amaç & $\begin{array}{l}\text { Öğrencilerin İngilizceyi doğru ve } \\
\text { uygun şekilde kullanması }\end{array}$ & $\begin{array}{l}\text { Öğrenenlerin İngilizce öğrenmeye } \\
\text { olan ilgilerini arttırmak ve bu dili } \\
\text { gerçek yaşamda kullanabilmeleri }\end{array}$ \\
\hline $\begin{array}{l}\text { Programin } \\
\text { Amaçları }\end{array}$ & Kazanımlar & $\begin{array}{l}\text {-Kişisel bilgi ve ihtiyaçlarını ifade } \\
\text { etme, } \\
\text {-Temel kelime bilgisine sahip olma, } \\
\text {-Birkaç basit dilbilgisi kuralını ve } \\
\text { cümle yapısını kullanma, } \\
\text {-Öğrenilmiş sınırlı sayıdaki kelime- } \\
\text { leri doğru telaffuz etme }\end{array}$ & $\begin{array}{l}\text {-ìlgi, istek, duygu ve rahatsızlıkla- } \\
\text { rını karşılarındakinin anlayacağı } \\
\text { şekilde ifade etme, } \\
\text {-Selamlaşma ve izin istemeleri, } \\
\text { kişisel düşüncelerini, beğenilerini } \\
\text { ve ihtiyaçlarını belirtme, } \\
\text {-Saat sorma ve yol tarifi gibi gün- }\end{array}$ \\
\hline
\end{tabular}


-Sık karşılaşılan ifadeleri kullanmaları ve taklit etmeleri,

-Öğrendikleri ifadeleri doğru olarak yazma,

-Selamlaşma, teşekkür etme, vedalaşma gibi günlük dilde basit iletişim kurma lük dilde ihtiyacını duyacağı ifadeleri kullanma,

-Temel dil işlevlerini yerine getirme,

-Yeteneklerini ve zorunlu olduğu şeyleri ifade etme,

-Alışkanlıklarını ve olay anında yaşadiklarını anlatma

3.3 Programın Temel Yaklaşımı, Öğretim Yöntem ve Teknikleri

2006 ve 2013 programlarının her ikisinde de iletişimsel yaklaşım benimsenmiştir. Her iki programda da iletişimsel ve gerçekçi dil kullanımının dilin öğrenilmesi için daha doğal ortam yaratacağı savunulmuştur. Ayrıca, 2013

Tablo 4. Programlarda Benimsenen Yaklaşım, Model ve Teknikler

\begin{tabular}{|c|c|c|}
\hline & 2006 Programı & 2013 Programı \\
\hline $\begin{array}{l}\text { Dil Öğretme Yak- } \\
\text { laşımı }\end{array}$ & İletişimsel Yaklaşım & $\begin{array}{l}\text { İletişimsel Yaklaşım } \\
\text { (Gerçekçi İletişim Ortamları) }\end{array}$ \\
\hline $\begin{array}{l}\text { Benimsenen Öğre- } \\
\text { tim Modeli }\end{array}$ & Eklektik Öğretim Modeli & Eklektik Öğretim Modeli \\
\hline $\begin{array}{l}\text { Kullanilan Teknik- } \\
\text { ler ve Ders Mater- } \\
\text { yalleri }\end{array}$ & $\begin{array}{l}\text { Öğrencilerin kendilerini rahat his- } \\
\text { settikleri eğlenceli öğrenme ortamla- } \\
\text { rı sağlayacak teknikler; } \\
\text { Oyunlar, Hikayeler, Şarkılar Şiirler, } \\
\text { Bilmeceler, Tekerlemeler, Dra- } \\
\text { ma/Rol Yapma, El Becerileri Etkin- } \\
\text { likleri }\end{array}$ & $\begin{array}{l}\text { Öğrencilerin kendilerini rahat hissettikleri } \\
\text { eğlenceli öğrenme ortamları sağlayacak } \\
\text { teknikler; } \\
\text { Oyunlar, Hikayeler, Şarkılar Şiirler, Bilme- } \\
\text { celer, Tekerlemeler, Drama/Rol Yapma, } \\
\text { Çizme, Boyama, Dinleme-Konuşma, An- } \\
\text { latma, El Becerileri Etkinlikleri, Resimler, } \\
\text { Posterler, Gerçekçi (Authentic) Materyal- } \\
\text { ler, çizme }\end{array}$ \\
\hline
\end{tabular}

Her iki programda da tek bir öğretim yaklaşımının İngilizce öğretimi için yetersiz kalacağından dolayı eklektik öğretim yaklaşımı tercih edilmiştir. Böylelikle İngilizce öğretiminin etkililiği için farklı tekniklerin kullanılması amaçlanmıştır. 2006 programından farklı olarak 2013 programında eylem araştırması yaklaşımına vurgu yapılmış, öğrenci grubunun ihtiyaç ve beklentileri göz önünde bulundurulmuştur. 2006 programında Avrupa Dil Pasaportu'nun (ELP) iletişimi geliştirmeyi amaçlayan her yabancı dil programını desteklediği üzerinde durulmuştur. ELP ile dil öğrenme surecini, öğrenciler için daha saydam yapmak, düşünme ve kendini değerlendirme programında yabancı dilin yalnızca ders olarak değil aynı zamanda iletişimi sağlamak için gerçekçi bağlamlarda kullanılmasının asıl odak noktası olduğu belirtilmiştir. Tablo 4' de programların dil öğretme yaklaşımı, benimsenen öğretim modeli ve teknikleri verilmiştir. ler, çizme

kapasitelerini geliştirmelerine yardımcı olmak ve böylece yavaş yavaş onların kendi öğrenmeleri için daha çok sorumluluk üstlenmelerini sağlamak, öğrencileri öğrenmeyi öğrenme ile eleştirel düşünmeye yönlendirmek ve dil öğrenmenin daha anlamlı hale gelmesini sağlamak amaçlanmıştır. 2013 programında ise Avrupa Ortak Dil Kriterleri (CEFR)'nin ilkeleri ve tanımları üzerinde durulmuştur. Avrupa Ortak Dil Kriterleri, öğrencilerin İngilizceyi etkili ve doğru kullanmaları için gerçekçi iletişim ortamları sağlamanın önemini vurgulamaktadır. Buna bağlı olarak yeni öğretim programı gerçekçi iletişim ortamları kurmayı amaçlamıştır. İngilizce bir ders olarak değil iletişimi 
sağlayan bir araç olarak görülmüştür. Genel olarak değerlendirildiğinde her iki programda da öğrencilerin kendilerini rahat hissedecekleri ve eğlenceli öğrenme ortamları sağlayacak tekniklerin kullanılması önerilmiştir.

Benimsenen iletişimci yaklaşım ve eklektik öğretim yaklaşımı ile birlikte 2006 ve 2013 programlarında anlamaya odaklanılmış, gerçekçi iletişim ortamları sağlayacak tekniklerin kullanılması önerilmiştir. Dinleme ve konuşma etkinlikleri, oyunlar, hikayeler, şarkılar, dramalar, şiirler, tekerlemeler ve görsel materyallerle yürütülen etkinlikler her iki programda da sınıf içerisinde kullanılabilecek teknikler arasında yer verilmiştir. Fakat 2013 programinda bu tekniklerden farklı olarak gerçek yaşamdan seçilmiş (authentic) materyallerin kullanıldığı etkinlikler de tercih edilmiştir. Böylece öğrencilere İngilizcenin gerçek hayatta kullanılan haliyle karşılaşma fırsatı verilmiş olacaktır.

\section{4 Ölçme ve Değerlendirme Anlayışı}

Ölçme ve değerlendirme anlayışı her iki programda da aynıdır. Dil öğrenme bir beceri olduğu için son yaklaşımlarda dikkatlerin "ürün” den "süreç" e kaydığı görülmektedir. 2006 ve
2013 programlarında öğretimde süreç değerlendirme yapmanın diğer bir deyişle performans değerlendirmenin önemine vurgu yapılmıştır. Bunun için öğrencilerin bilgi, beceri ve performanslarını sergileyebilecekleri, dil yeterlilikleri ve gelişim sürecinin kolayca takip edilebileceği ölçme araç ve tekniklerinin kullanılması önerilmiştir. Aynı zamanda, öğrencilerin kendilerini değerlendirebileceği öz değerlendirme yaklaşımı da benimsenmektedir. 2006 programında değerlendirme süreçlerinin öğretim yöntem ve teknikleriyle aynı çizgide olması gerektiği belirtilmiş ve Avrupa Dil Portfolyosu'nda yer alan ölçme araçları önerilmiştir. Öğrencilerin dil yeteneklerini ortaya koyan dil pasaportu, dil öğrenme geçmişlerini gösteren dil özgeçmişi ve yaptıkları ürünleri sergilemelerini sağlayan portfolyo, önerilen bu araçların arasında yer almaktadır. Yazılı sınavlar öğrencilerin kaygı düzeyini arttırdığından dolayı öğrencilerin süreçteki performanslarının değerlendirilmesini sağlayan portfolyo ile değerlendirme, sınıf içi değerlendirme, öz değerlendirme, öğretmen gözlemleri ve öğrenci yazılı ürünlerini değerlendirme 2006 programinda yer alan alternatif değerlendirme türlerindendir.

Tablo 5. Programlarda Değerlendirme Anlayışı ve Türleri

\begin{tabular}{lll}
\hline $\begin{array}{l}\text { Değerlendirme } \\
\text { Anlayışı }\end{array}$ & 2006 Progreç Değerlendirme & 2013 Programı \\
\hline \multirow{3}{*}{$\begin{array}{l}\text { Değerlendirme } \\
\text { Türleri }\end{array}$} & Portfolyo Değerlendirme & Süreç Değerlendirme \\
& Sını İçi Değerlendirme & Öz ve Akran Değerlendirme \\
& Öz Değerlendirme & Proje ve Portfolyo Değerlendirme \\
& Öğretmen Gözlemleri & Öğretmen Gözlemleri \\
& Öğrenci Yazılı Ürünleri Değerlendirme & Kalem-Kağıt Sınavları \\
\hline
\end{tabular}

Tablo 5' de görüldüğü gibi 2013 programında da süreç değerlendirme yine odak noktası olmuştur. Programda dört temel değerlendirme etkinliğinden söz edilmektedir. Bunlardan ilki öz değerlendirme ve akran değerlendirmedir. Avrupa Ortak Dil Kriterleri (CEFR)'nin tavsiye ettiği öz değerlendirme öğrencilerin kendi gelişimlerini, başarılarını ve iletişimsel yetkinliklerini takip edebilmeleri açısından önemlidir. 2006 programından farklı olarak yeni programda öğrencilerin birbirlerini değerlendirmelerini sağlayan akran değerlendirmenin kullanılmasının faydalı olacağı belirtilmiştir. İkinci değerlendirme türü proje ve portfol- 
yo değerlendirmedir. Proje ve portfolyo değerlendirme ile birlikte öğrencilerin dil öğrenme süreci hakkında sürekli takip imkanı sağlanmış olacak böylelikle sadece ürüne bakarak yapılacak eksik değerlendirmelerin önüne geçilmiş olacaktır. Programda adı geçen üçüncü değerlendirme türü ise öğretmen gözlemleri ve değerlendirmeleridir. Öğretmenlerin ders esnasında öğrencileri etkinlik yaparken gözlemlemesi ve onlar hakkında takip cetvelleri ve rubrikler oluşturması öğrenme-öğretme sürecinin değerlendirilmesini sağlayacaktır. Kalem kâğıt sınavları olarak adı geçen yazılı sınavlar ise 2013 programında yer alan son değerlendirme türüdür. Daha çok ürün değerlendirmeye uygun olan bu değerlendirme yöntemi uzun yıllardır kullanılagelmektedir. Fakat son yıllarda ortaya çıkan süreç odaklı çağdaş dil öğretim yaklaşımlarıyla birlikte popülerliğini kaybetmiş durumdadir.

\subsection{Ana Dil Kullanımı}

2006 ve 2013 programları dil kullanımı açısından benzerlik göstermektedir. Her iki programda da iletişimsel yaklaşım benimsendiği için derslerde iletişimin İngilizce sürdürülmesi önerilmektedir. 2006 programında amaç, öğretmen ve öğrencilerin sınıfta her zaman İngilizce konuşmasıdır. Bu programa göre öğretmenler her koşulda, öğrenciler ise konuşmaya hazır oldukları anda derslerde tamamen İngilizce konuşmalıdırlar. Ayrıca, öğretmenler ders boyunca ana dile geçiş yapmak için nedenler aramamalılar ve öğrencilere sürekli İngilizce konuşarak iyi bir model olmalıdırlar. 2013 programında ise iletişimin mümkün olduğunca İngilizce yürütülmesi gerektiği vurgulanmaktadır. Fakat 2006 programından farklı olarak güncellenen programda ana dil kullanımı yasaklanmaz ve engellenmez, gerektiğinde kullanılabilir. Öğrenciler, İngilizce öğrenirken kendi ana dillerine de sayg duyar ve dil gelişimlerinin önemli bir parçası olarak görürler.

\section{6 Üniteler}

İki öğretim programının ünite tasarım süreci ve üniteleri incelendiğinde pek çok benzerlik ve farklılığın bir arada olduğu görülmektedir. Programların benzer yönleri incelendiğinde her iki programda da program geliştirme modeli olarak karma tip model benimsendiği görülmektedir. Karma tip program geliştirme modelinde yabancı dil öğretimi bir bütün olarak ele alınır ve programda dildeki yapılara, durumlara, konulara, becerilere, işlevlere, görevlere beraber yer verilir. 2006 programı ünite planlarında konu, beceriler, bağlam (durum), işlevler ve görevler öğelerine yer verilirken, 2013 programında konu, iletişimsel işlevler, beceriler, dil ve kelime kullanımı, önerilen metin ve aktivite çeşitleri ve değerlendirme öğelerine yer verilmektedir. Bu açıdan bakıldığında, 2013 programı ünite planlarında öğelerin sayısının arttığ1; kelime kullanımı, metin-aktivite çeşitleri ve değerlendirme öğelerinin plana dahil edildiği görülmektedir.

Programlarda ünite tasarımı konusundaki bir diğer benzer yön ise her ikisinde de içerik düzenleme yaklaşımı olarak sarmal program modelinin benimsenmesidir. Her iki programda da dil öğrenmede eski öğrenilenlerle ilişki kurulmasının gerekliliği üzerinde durulmuş, öğrenilenlerin bir bütün halinde ilerlemesi için önceki yıllarda veya ünitelerde öğrenilenlere ihtiyaç duyulacağı vurgulanmıştır. Ünite tasarımı konusundaki bu belirgin benzerliklerin yanı sıra pek çok farklılığın da olduğu gözden kaçırılmamalıdır. 2013 programında bir önceki programdan farklı olarak ünite planlaması konusunda öğretmene de inisiyatif verilmiştir. Öğretmenlerin program tarafından belirlenen konular çerçevesinde öğrencilerin ilgi, ihtiyaç 
ve beklentileri ile içerisinde bulundukları durumlar göz önünde bulundurularak, seçeceği materyal ve etkinliklerle, ünite planlaması yapabileceği vurgulanmıştır. 2006 programında ise ünitelerde yapılacak bütün etkinlikler hazır olarak verildiği için hedef öğrenci kitlesi ihtiyaçları göz ardı edilerek standart bir plan izlenmiştir.
2006 ve 2013 programlarında üniteler arasındaki en büyük farklılık ise ünite sayılarında ve konularındadır. 2006 programına göre 14 üniteden oluşan ünite sayısı 2013 programında 10'a düşürülmüş ve ünite konularında bazı değişiklikler yapılmıştır.

Tablo 6. Programlardaki Üniteler

\begin{tabular}{lll}
\hline & 2006 Programi & 2013 Program1 \\
\hline Ünite 1: Countries & Ünite 1: My Daily Routine \\
Ünite 2: Regions & Ünite 2: My Town \\
Ünite 3: Cities & Ünite 3: Hello \\
Ünite 4: School Life & Ünite 4: Games and Hobbies \\
Ünite 5: School Stores & Ünite 5: Health \\
Ünite 6: Physical Education & Ünite 6: Movies \\
Ünite 7: Likes and Dislikes & Ünite 7: Party Time \\
Ünite 8: My Favourite Activities & Ünite 8: Fitness \\
Ünite 9: Farm Life & Ünite 9: The Animal Shelter \\
Ünite 10: Cartoon Charachters & Ünite 10: Festivals \\
& Ünite 11: Personal Possesions & \\
Ünite 12: Health Problems & \\
Ünite 13: Fun at the Park & \\
Ünite 14: Help & \\
\hline
\end{tabular}

Tablo 6' ya göre 2006 programında ünite sayısı fazla görünse de 2013 programinda benzer konular birleştirilerek aynı ünite içerisinde yer verilmiştir. Örneğin; 2006'daki "Countries", "Regions" ve "Cities" ünitelerinin içeriği 2013 programında iki ünitenin içerisine alınarak "My Town" ve "Hello" üniteleri başlığı altında toplanmıştır. Fakat bunun yanında 2013 programında bazı çıkarma ve eklemeler yapılmıştır. Daha önceki programda yer alan "School Life", "School Stores" ve "Help" üniteleri bazı kazanımları dışında güncellenen programdan tamamen çıkarılmış, "My Daily Routine”, "Movies" ve "Festivals" üniteleri programa yeni dahil edilmiştir.

\subsection{Beceriler ve İşlevler}

Yabancı dil öğrenmenin temelini oluşturan ve okuma, dinleme, konuşma, yazma faaliyetleri- nin bütününü kapsayan "beceriler" (skills) ve dilin kullanımını ifade eden dilişlevleri (functions) İngilizce öğretim programlarında dil öğrenme sürecinde öğrencilerin kazanmaları gereken temel unsurlar olarak değerlendirilebilir. Özellikle iletişimsel yaklaşımın benimsenmeye başlanmasıyla birlikte anlama ve konuşmaya odaklanılması bu iki unsurun programlardaki işlevselliğini arttırmıştır. 2006 ve 2013 programlarında da iletişimsel yaklaşım benimsendiği için beceriler ve işlevler üzerinde özellikle durulmuştur. Her ne kadar programlarda dil becerileri ve işlevleri benzer şekilde ele alınmış gibi görünse de bazı temel farklılıklar bulunmaktadır. Örneğin; 2006 programında beceriler ve işlevler, ünite planlarında ayrı ayrı ele alınırken 2013 programında iletişimsel beceriler ve işlevler başlığı altında toplanmıştır. Bunun yanında 2006 programının ünite planlarında dinleme (listening), okuma (reading), 
yazma (writing) ve konuşma (speaking) olmak üzere dört beceriye yer verilirken, 2013 programından yazma becerisi çıkartılmıştır. Bu farklılığın temel nedeni olarak da yeni programla birlikte 5 . sınıf seviyesinde öğrencilerin sadece sınırlı yazma yapabileceğinin düşünülmesi gösterilmektedir. Aşağıdaki tabloda sınıf seviyelerine göre öğrencilerin beceri gelişimi ele alınmıştır.

Tablo 7. 2013 Programında Becerilerin Yaşlara Göre Dağılımı

\begin{tabular}{|c|c|c|}
\hline $\begin{array}{l}\text { Seviyeler } \\
\left(\text { ADOÇEP*) }^{*}\right.\end{array}$ & Sinıf (Yaş) & Geliştirilmesi Hedeflenen Beceriler \\
\hline \multirow{4}{*}{ A1 } & $2(6-6,5)$ & Dinleme ve Konuşma \\
\hline & $3(7-7,5)$ & Dinleme ve Konuşma \\
\hline & & Çok Sınırlı Okuma ve Yazma \\
\hline & $4(8-8,5)$ & $\begin{array}{l}\text { Dinleme ve Konuşma } \\
\text { Çok Sınırlı Okuma ve Yazma }\end{array}$ \\
\hline \multirow[b]{2}{*}{ A1 } & $5(9-9,5)$ & $\begin{array}{l}\text { Dinleme ve Konuşma } \\
\text { Sinırlı Okuma } \\
\text { Çok Sınırlı Yazma }\end{array}$ \\
\hline & $6(10-10,5)$ & $\begin{array}{l}\text { Dinleme ve Konuşma } \\
\text { Sinırlı Okuma } \\
\text { Çok Sınırlı Yazma }\end{array}$ \\
\hline \multirow[b]{2}{*}{ A2 } & $7(11-11,5)$ & $\begin{array}{l}\text { Temel: Dinleme ve Konuşma } \\
\text { Yan: Okuma ve Yazma }\end{array}$ \\
\hline & $8(12-12,5)$ & $\begin{array}{l}\text { Temel: Dinleme ve Konuşma } \\
\text { Yan: Okuma ve Yazma }\end{array}$ \\
\hline
\end{tabular}

*Avrupa Dilleri Öğretimi Ortak Çerçeve Programı

Tablo 7 incelendiğinde 5. sınıf öğrencilerinin geliştirmesi beklenen beceriler olarak dinleme ve konuşma, 25-26 sözcüğe kadar okuma ve cümle düzeyinde yazma (çok sınırlı yazma) verilmiştir. Verilen bu program “Avrupa Dilleri Öğretimi Ortak Çerçeve Programı"nda belirtilen "A2" seviyesine uygun olarak hazırlanmıştır. Bu yüzden, dil öğrenme standartları göz önünde bulundurularak hazırlanan 2013 programında 5. sınıf seviyesinde, daha önceki prog- ramda var olmasına rağmen, yazma kazanımlarına yer verilmemiştir. 2006 programında ise böyle bir standart gözetilmediği için dört beceriye ait kazanımlar ünite planlarında tek tek ifade edilmiştir.

Aşağıda verilen tablo $8^{\prime}$ de her iki programın bütün ünitelerine ait beceri kazanım sayıları verilmiştir.

Tablo 8.Programlardaki Beceri Kazanım Sayıları

\begin{tabular}{lcccclccc}
\hline \multicolumn{3}{c}{ 2006 Programı } & \multicolumn{1}{c}{2013 Programı } \\
\hline Ünite & Dinleme & Konuşma & Okuma & Yazma & Ünite & Dinleme & Konuşma & Okuma \\
\hline Countries & 2 & 3 & 3 & 2 & $\begin{array}{l}\text { My Daily } \\
\text { Routine }\end{array}$ & 2 & 2 & 1 \\
Regions & 2 & 4 & 3 & 1 & My Town & 1 & 2 & 1 \\
Cities & 2 & 4 & 2 & 1 & Hello & 1 & 2 & 1 \\
School Life & 2 & 3 & 4 & 1 & Games and & 1 & 2 & 1 \\
School Sto- & 2 & 6 & 2 & 1 & Health & 1 & 2 & 1 \\
\hline
\end{tabular}




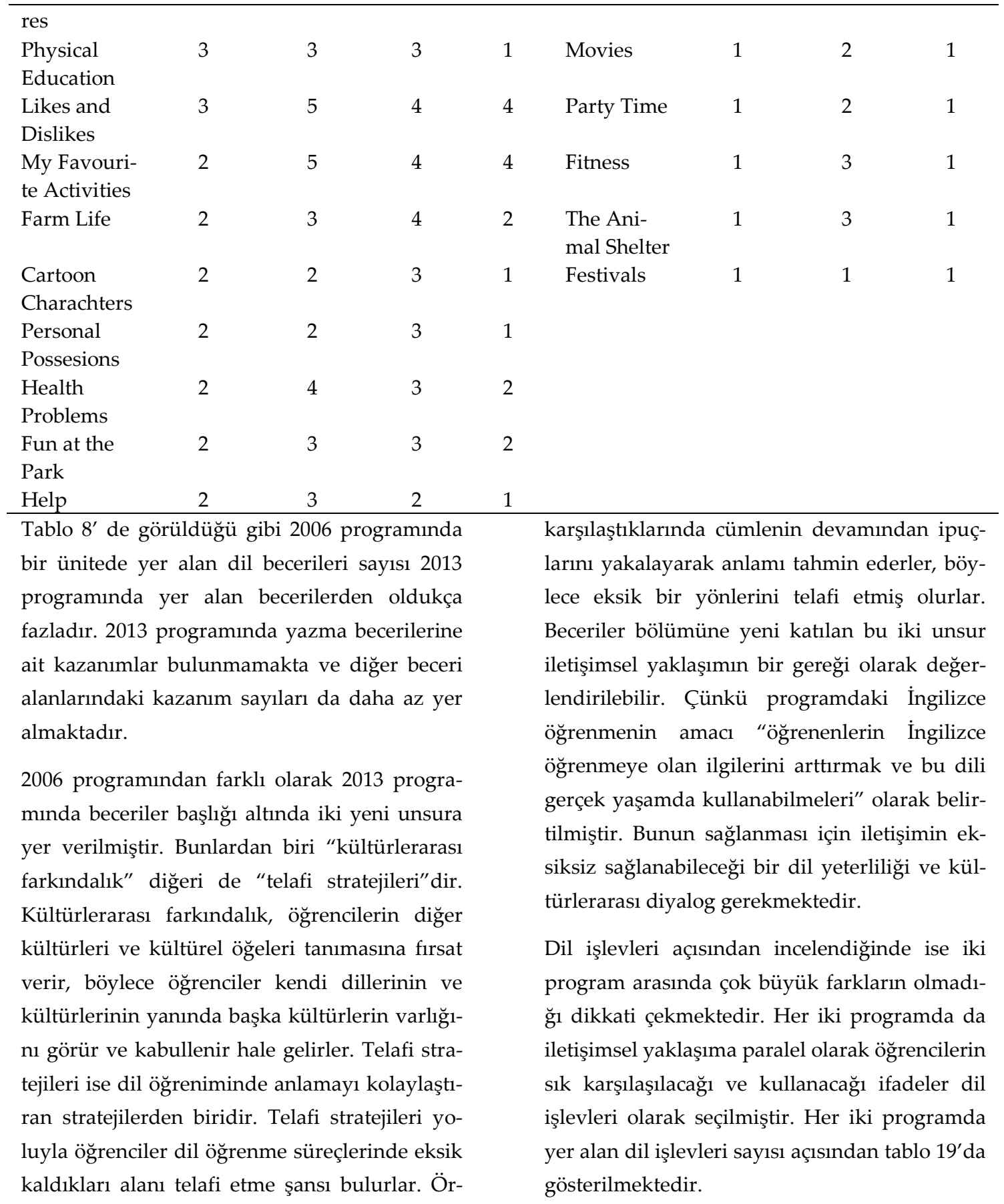

Tablo 9. Programlardaki Dil İşlevleri Sayısı

\begin{tabular}{lcllc}
\hline & \multicolumn{2}{c}{2006 Programı } & \multicolumn{2}{c}{2013 Programı } \\
\hline & Ünite & Dil İşlevleri & Dil İşlevleri \\
\hline Countries & 2 & My Daily Routine & 3 \\
Regions & 3 & My Town & 3 \\
Cities & 4 & Hello & 6 \\
\hline
\end{tabular}




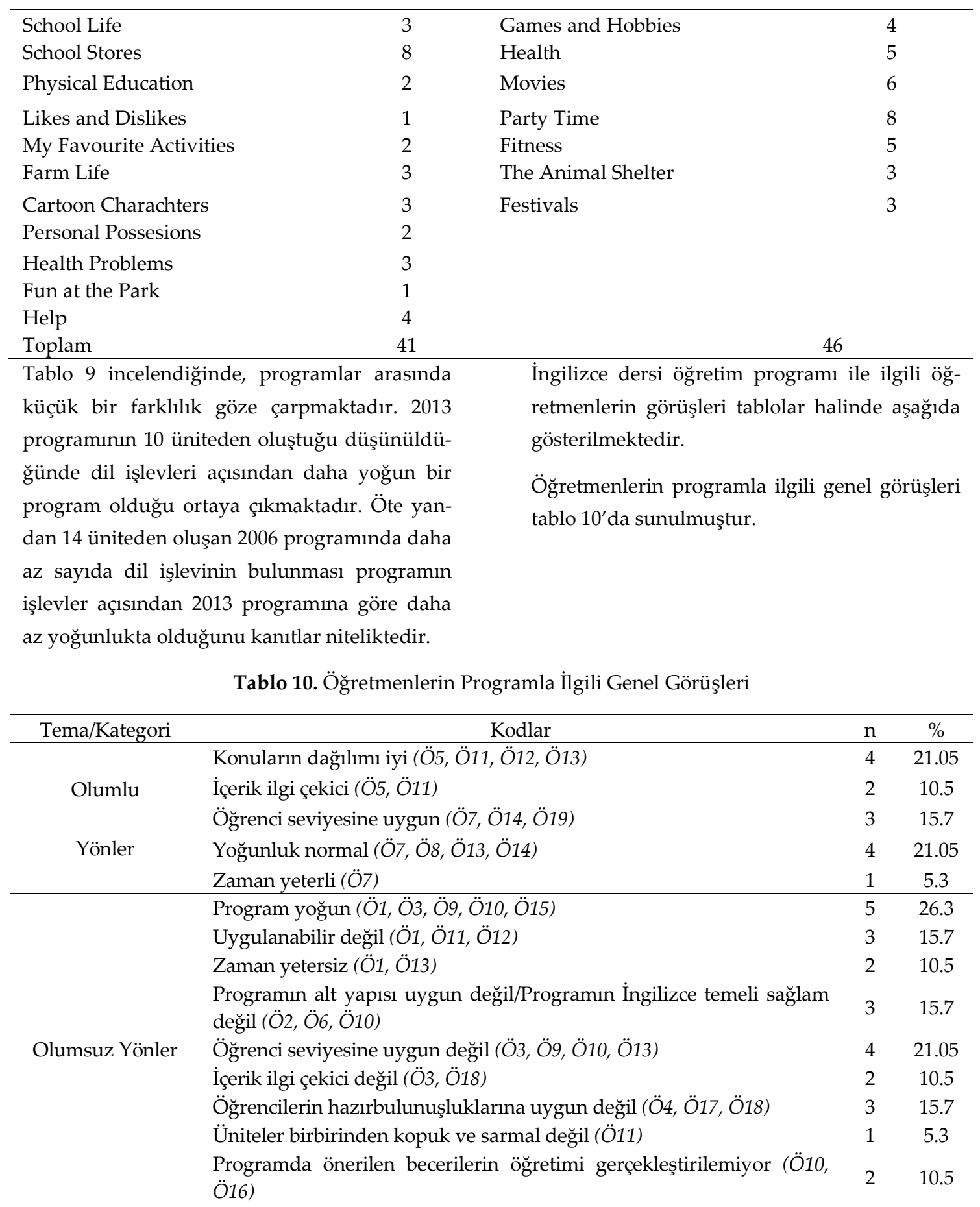

Tablo 10 incelendiğinde, öğretmenlerin programla ilgili temel görüşleri; programdaki "olumlu yönler" ve "olumsuz yönler" temaları çerçevesinde ele alınmıştır. Programla ilgili olumlu yönlere ilişkin öğretmenlerin görüşleri en çok \% 21.05 oranında konuların dağılımının iyi olduğu ve yoğunluğun normal olduğu şek- lindedir. Diğer görüşler, \%15.7 oranında programın öğrenci seviyesine uygun olduğu ve \%10.5 oranında içeriğin ilgi çekici olduğu şeklindedir. Öğretmenlerin olumlu görüşleri aşağıda sunulmaktadır. 
"...Programda gramer dağılımının çok uygun olduğunu düşünüyorum... Temalarm öğrenci ilgisine uygun olduğunu düşünüyorum." (Ö11)

"Konular eski programa göre daha iyi yerleştirilmiş... Yeni program daha uygun." (Ö12)

"Programda yoğunluk normal... Konularm yerleşim planı iyi..." (Ö13)

Programla ilgili olumsuz yönlere ilişkin öğretmenlerin görüşleri en çok \%26.3 oranında programın yoğun olduğu şeklindedir. Diğer görüşler sırasıyla, \%21.05 oranında programın öğrenci seviyesine uygun olmadığı, \%15.7 oranında programın uygulanabilir olmadığı, alt yapısının uygun olmadığı/İngilizce temelinin sağlam olmadığı ve öğrencilerin hazırbulunuşluklarına uygun olmadığı, \%10.5 oranında zamanın yetersiz olduğu, içeriğin ilgi çekici olmadığı ve programda önerilen becerilerin öğretimde gerçekleştirilemediği, \%5.3 oranında ise ünitelerin birbirinden kopuk ve sarmal olmadığı şeklindedir. Olumsuz görüşler aşağ1daki gibi sıralanmıştır.

"2013'de hazırlanan yeni Ingilizce dersi öğretim programında ders saatinin düşürülmesi dersin verimliliğini olumsuz bir şekilde etkilemiştir. Programın ise yoğun ve uygulanabilir olmadığını düşünüyorum." (Ö1)

"Yoğun ve gereksiz konulara yer verilen bir program olduğunu düşünüyorum. Bu seviyeye ve bu ilgi grubuna ait öğrencilere hitap etmeyen bir program olduğunu düşünüyorum."(Ö3)

"Bir önceki programin bu programdan daha iyi olduğunu düşünüyorum. Çocukların hazırbulunuş- luklarma uygun olmayan bir program. Daha önce hiç karşılaşmadıkları konuların programda yer almasının hiçbir etkililik să̆lamadiğını düşünüyorum."(Ö4)

"Programın kötü olduğunu düşünüyorum. Programın Ingilizce temelinin să̆lam olmadı̆̆ıın düşünüyorum."(Ö6)

"Programın seviyeye uygun olmadiğı kanaatindeyim. Daha temel becerilerin verilmesi gerektiğini düşünüyorum. Program hakkında çok da olumlu bir fikrim yok. Bütün sinıfa hitap eden bir program olmadı̆̆ııı düşünüyorum. Müfredatın takip edilmesi zor ve alt yapı hazır değil."(Ö10)

"Konuların ve ünitelerin kopuk olduğunu düşünüyorum. Yoğun programın daha kısa bir programa yerleştirildiğini düşünüyorum. Eski programın daha rahat uygulamaya konulduğunu düşünüyorum... Programın sarmal olduğunu düşünmüyorum..."(Ö11)

Öğretmenlerin programla ilgili bilgi edinme durumlarına yönelik görüşleri incelendiğinde görüşme yapılan on dokuz öğretmenden sadece bir öğretmen (Ö10) bilgilendirme yapıldı̆̆ını "Okulda bir bilgilendirme toplantısina katıldım. Merkezi bir toplantı olmadı." (Ö10) şeklinde dile getirirken, on sekiz öğretmen ise kendilerine herhangi bir bilgilendirme yapılmadığını ifade etmişlerdir. Öğretmenlerin programla ilgili bilgi edinmek için yaptıkları çalışmalar tablo $11^{\prime}$ de sunulmuştur.

Tablo 11. Öğretmenlerin Programla İlgili Bilgi Edinme Durumlarına Yönelik Görüşleri

\begin{tabular}{|c|c|c|c|}
\hline $\begin{array}{l}\text { Tema (Kategori- } \\
\text { ler) }\end{array}$ & Kodlar & $\mathrm{n}$ & $\%$ \\
\hline \multirow{3}{*}{$\begin{array}{l}\text { Bilgi edinmek } \\
\text { için yapılan ça- } \\
\text { lışmalar }\end{array}$} & $\begin{array}{l}\text { İnternet sitelerinden (forumlar, sosyal ağlar) bilgi edindim. (Ö1, Ö2, } \\
\text { Ö3, Ö4, Ö5, Ö6, Ö8, Ö9, Ö12, Ö13, Ö14, Ö15, Ö16, Ö17, Ö18, Ö19) }\end{array}$ & 16 & 84.2 \\
\hline & $\begin{array}{l}\text { Zümre öğretmen ve öğretmen arkadaşlarla iletişim içinde bilgi edin- } \\
\text { dim. (Ö2, Ö5, Ö14, Ö15) }\end{array}$ & 4 & 21.05 \\
\hline & Sinıfta deneyimleyerek öğrendim. (Ö2) & 1 & 5.3 \\
\hline
\end{tabular}




\begin{tabular}{lcc}
\hline Öğretim programını, yıllık ders planını inceledim. (Ö4, Ö11, Ö16) & 3 & 15.7 \\
Kitabı inceledim. (Ö4) & 1 & 5.3 \\
Okulda yapılan bilgilendirme toplantısına katıldım. (Ö10) & 1 & 5.3 \\
Yüksek lisans eğitimim sürecinde program hakkında bilgi edindim. & 1 & 5.3 \\
(Ö7) & &
\end{tabular}

Tablo 11 incelendiğinde, programla ilgili bilgi edinmek için yaptıkları çalışmalara ilişkin öğretmenlerin görüşleri en çok \%84.2 oranında internet sitelerinden (forumlar, sosyal ağlar) bilgi edindikleri şeklindedir. Öğretmen görüşlerinden bazıları;

"Bilgilendirme yapılmadı. Internet sitesinden bilgi edindim." (Ö1)

"Herhangi bir bilgilendirme yapılmadı. Kitabı inceleyerek, yıllık planı inceleyerek ve internet aracillğıyla kendi çabamla bilgi edindim." (Ö4)

"Herhangi bir bilgilendirme yapılmadı. Yıllik planı inceleyerek ve internetteki forumlardan bilgi edindim." (Ö16) şeklindedir.

Öğretmenlerin \%21.05 oranında zümre öğretmen ve öğretmen arkadaşlarla iletişim içinde bilgi edindikleri, \%15.7 oranında öğretim programını ve yıllık ders planını inceleyerek bilgi edindikleri, \%5.3 oranında sinıfta deneyimleyerek, kitabı inceleyerek, okulda yapılan bilgilendirme toplantısına katılarak ve yüksek lisans eğitimi sürecinde program hakkında bilgi sahibi oldukları şeklindedir. Öğretmenlerin görüş- lerinden alınan birebir alıntılar aşağıda sunulmaktadır.

"Program hakkında kesinlikle bilgilendirilme yapılmadi. Program hakkndaki bilgilere tamamen kendi çabamla ve ayn okuldaki Ingilizce zümremle sürekli iletişim içinde olarak ulaştım. Aslında programı sinıf içinde öğrencilerle yaşayarak deneyimleyerek öğrendim." (Ö2)

"Hayır, bilgilendirme yapılmadı. Yüksek lisans programından daha yakın takip ettiğim için program hakkında bilgi sahibi oldum."(Ö7)

"Bilgilendirme yapılmadı. Öğretim programın inceleyerek ve yillık ders planin inceleyerek bilgi edindim. Bunun da yeterli olmadığını düşünüyorum." (Ö11)

"Bilgilendirme yapulmadi. Internetten kendi isteğimle ve çabamla ulaştım. Arkadaşlara danışarak bilgi edindim." (Ö14)

Öğretmenlerin programın dört temel beceriyi gerçekleştirebilme durumuna ilişkin görüşleri tablo 12 'de sunulmuştur.

Tablo 12. Öğretmenlerin Programın Dört Temel Beceriyi Gerçekleştirebilme Durumuna İlişkin Görüşleri

\begin{tabular}{|c|c|c|c|c|c|c|c|c|}
\hline \multirow{2}{*}{$\begin{array}{l}\text { Temalar } \\
\text { goriler) }\end{array}$} & \multirow{2}{*}{ (kate- } & \multicolumn{4}{|c|}{ Olumlu } & \multicolumn{3}{|l|}{ Olumsuz } \\
\hline & & Kodlar & & $\mathrm{n}$ & $\%$ & Kodlar & $\mathrm{n}$ & $\%$ \\
\hline \multirow{3}{*}{$\begin{array}{l}\text { Okuma } \\
\text { leri }\end{array}$} & \multirow{3}{*}{ Beceri- } & $\begin{array}{l}\text { Seviyeye } \\
\text { (Ö15, Ö19) }\end{array}$ & uygun & 2 & 10.5 & $\begin{array}{l}\text { Öğrenci seviyesinin üstünde (Ö4, } \\
\text { Ö7, Ö10, Ö16, Ö17, Ö18) }\end{array}$ & 6 & 31.5 \\
\hline & & Yeterli düzey & de (Ö5) & 1 & 5.3 & $\begin{array}{l}\text { Yeterli düzeyde değil (Ö9, Ö11, Ö12, } \\
\text { Ö13) }\end{array}$ & 3 & 15.7 \\
\hline & & $\begin{array}{l}\text { Parçalar ilg } \\
\text { (Ö19) }\end{array}$ & çekici & 1 & 5.3 & $\begin{array}{l}\text { Etkinlikler becerilerle uyumlu değil } \\
\text { (Ö9) }\end{array}$ & 1 & 5.3 \\
\hline \multirow{3}{*}{$\begin{array}{l}\text { Dinleme } \\
\text { leri }\end{array}$} & \multirow{3}{*}{ Beceri- } & $\begin{array}{l}\text { Seviyeye uyg } \\
\text { Ö8, Ö15, Ö19 }\end{array}$ & un (Ö3, & 4 & $\begin{array}{c}21.0 \\
5\end{array}$ & $\begin{array}{l}\text { Yeterli düzeyde değil (Ö3, Ö5, Ö11, } \\
\text { Ö12, Ö16) }\end{array}$ & 5 & 26.3 \\
\hline & & $\begin{array}{l}\text { Parçalar ilg } \\
\text { (Ö19) }\end{array}$ & çekici & 1 & 5.3 & $\begin{array}{l}\text { Öğrenci seviyesinin üstünde (Ö2, } \\
\text { Ö4, Ö7, Ö17, Ö18) }\end{array}$ & 5 & 26.3 \\
\hline & & & & & & Materyal yok (Ö9, Ö10, Ö17) & 3 & 15.7 \\
\hline
\end{tabular}


Seviyeye uygun (Ö8, Ö11)

2 10.5

Öğrenci seviyesinin üstünde (Ö1,

Ö2, Ö3, Ö7, Ö9, Ö17)

Uygulamada sikıntılar var (Ö4,Ö9,

Ö16)

$\begin{array}{ll}3 & 15.7\end{array}$

Konuşma Bece-

rileri

Diyaloglar yeterli

(Ö13)

Parçalar ezbere dayalı (Ö7, Ö15,

Ö18)

Ders kitabı eksik (Ö5, Ö10)

$\mathrm{Bu}$ becerilere yönelik kazanımların olmaması büyük eksiklik (Ö4, Ö5,

Yazma BecerileÖ6, Ö8, Ö9, Ö10, Ö11, Ö12, Ö13,

ri

Ö15, Ö16, Ö17, Ö18, Ö19)

Etkinlikler basit ve yetersiz (Ö7, Ö13)

“Okuma paragraflarının öğrenci seviyesinin üstün-

Tablo 12 incelendiğinde, programdaki dört temel beceri olan "okuma", "dinleme", "konuşma" ve "yazma" becerileri temaları çerçevesinde öğretmenlerin görüşleri "olumlu" ve "olumsuz" temaları şeklinde ifade edilmiştir. Öğretmenlerin okuma becerilerine yönelik olumlu görüşleri en çok \%10.5 oranında seviyeye uygun olduğu şeklindedir. Diğer görüşler, \%5.3 oranında okuma becerilerinin yeterli düzeyde olduğu ve okuma parçalarının ilgi çekici olduğu şeklindedir. Öğretmenlerin okuma becerilerine yönelik olumsuz görüşleri ise en çok \%31.5oranında okuma becerilerinin öğrenci seviyesinin üstünde olduğu şeklindedir. Diğer görüşler sırasıyla, \%15.7 oranında okuma becerilerinin yeterli düzeyde olmadığ ve \%5.3 oranında etkinliklerin becerilerle uyumlu olmadığı şeklindedir. Okuma becerisi ile ilgili olumsuz görüşlerden bazıları aşağıdaki gibidir.

"Çocukların seviyesinden kaynakl, okumada başartsızlıklar var. Okuma parçaları seviyeye uygun değil." (Ö7)

“Okuma becerileri, kelime yoğunluğu yüksek olan okuma parçalarına yer verildiği için seviyenin üstünde kalıyor." (Ö10)

“Okuma becerileri üzerinde yeterince durulmadığgnı düşünüyorum." (Ö11) de olduğunu düşünüyorum." (Ö15)

Öğretmenlerin dinleme becerilerine yönelik olumlu görüşleri en çok \%21.05 oranında dinleme becerilerinin seviyeye uygun olduğu şeklindedir. Bununla ilgili bir öğretmenin görüşü;

"Genel değerlendirme yaptığımızda dinleme becerileri de öğrenci seviyesine uygun." (Ö15) şeklindedir.

Diğer olumlu görüş ise \%5.3 oranında dinleme becerileri ile ilgili parçaların ilgi çekici olduğu şeklindedir. Öğretmenlerin dinleme becerilerine yönelik olumsuz görüşleri ise en çok \%26.3 oranında dinleme becerilerinin yeterli düzeyde olmadığı ve becerilerin öğrenci seviyesinin üstünde olduğu şeklindedir. Diğer görüş ise \%15.7 oranında dinleme becerileri için materyalin olmadığ şeklindedir. Dinleme becerisi ile ilgili verilen olumsuz görüşlerden bazıları;

"Dört temel beceriye geliştirme de programın eksik olduğunu düşünüyorum. Özellikle dinleme ve konuşma becerilerinin öğrenci seviyesinin üzerinde olduğunu düşünüyorum, ulaşılması gereken kazanımlar öğrenci profiline göre gerçekçi değil." (Ö2)

"Dinleme becerileri ile ilgili materyalin verilmemesi büyük bir sıkıntı. Kendi çabalarımla dinleme aktiviteleri yapıyorum." (Ö10) 
"Dinleme becerilerine daha fazla yer verilmesi gerektiğini düşünüyorum. Önce dinleme becerisi kazamadan konuşma mümkün değildir." (Ö11) .

"Dinleme aktivitelerinin öğrenci seviyesine uygun olmadığııı seviyenin üzerinde olduğunu dü̈şünüyorum." (Ö18) şeklindedir.

Öğretmenlerin konuşma becerilerine yönelik olumlu görüşleri en çok \%10.5 oranında becerilerin öğrenci seviyesine uygun olduğu şeklindedir. Bununla ilgili bir öğretmenin görüşü;

"Konuşma becerileri önem verilen bir beceri haline gelmiş. Kalıplar içinde verilen konuşma aktiviteleri seviyeye uygundur." (Ö11) şeklindedir.

Diğer olumlu görüş ise \%5.3 oranında diyalogların yeterli olduğu şeklindedir. Öğretmenlerin konuşma becerilerine yönelik olumsuz görüşleri ise en çok \%31.5 oranında konuşma becerilerinin öğrenci seviyesinin üstüne olduğu şeklindedir. Diğer görüşler sırasıyla \%15.7oranında uygulamada sıkıntılar yaşandığı ve konuşma becerilerine yönelik parçaların ezbere dayalı olduğu, \%10.5 oranında ders kitabının eksik olduğu şeklindedir. Dinleme becerisi hakkındaki olumsuz görüşlerden bazıları aşağıda sıralandırılmıştır.

"Dinleme ve konuşma becerileri öğrenci seviyesine göre ağır kalıyor. Konuşma aktiviteleri ezbere dayalı olduğu için içselleştirme mümkün olmuyor." (Ö7)

"Kitabın konuşma becerilerinde eksikliği mutlaka var. Bu yüzden kitabı birebir takip etmek yerine kitaptan yola çıkarak kendi etkinliklerimi düzenliyorum." (Ö10)

"Konuşma kalıpların içine sığdırılmış. Aktivitelerin yetersiz olduğunu düşünüyorum." (Ö15)

"Programda konuşma üzerinde çok durulsa da öğrenci konuşmalarım programda sinırlandırıldı̆̆ı- $n$ düşünüyorum. Kalıplar içinde ezbere dayah bir konuşma yaklaşımının var olduğunu düşünüyorum." (Ö18)

Öğretmenlerin yazma becerilerine yönelik olumlu görüşleri bulunmamaktadır. Olumsuz görüşler ise en çok \%73.6 oranında yazma becerilerine yönelik programda kazanımların olmamasının büyük eksiklik olduğu şeklindedir. Diğer görüşe ise \%10.5 oranında yazma becerilerine yönelik etkinliklerin basit ve yetersiz olduğu şeklindedir. Yazma becerisi ile alakalı öğretmenlerin olumsuz görüşlerinden alınan birebir alıntılar aşağıda sunulmaktadır.

"Yazma becerilerine yönelik sinff seviyesine bağhl olarak etkinliklerin basit kaldiğ a düşüncesine sahibim." (Ö7)

"Yazma becerileri programda eksik. Tamamen kendi etkinliklerimi uyarlyyorum." (Ö10)

"Programda yazma becerileri kazanımlarina yer verilmemiş. Kitapta yazma aktiviteleri olmasına rağmen kazanımlarda yok. Daha çok konuşma becerileri üzerinde durulmasının diğger becerileri olumsuz etkilediğini düşünüyorum." (Ö11)

"Yazma becerilerinin çok önemsenmediğgini 2. plana atıldığın düş̧ünüyorum. Açık ve net kazanımların olmaması da işimizi zorlaştırıyor. Yazma aktivitelerine daha fazla yer verilmeli." (Ö15)

"Yazma aktivitelerine yeterince yer verilmediği kanaatindeyim. Şu aşamada çok da önem verilmesinin uygun olmadığın düşs̈nüyorum." (Ö18)

Öğretmenlerin programda öğrenme-öğretme sürecinde yer alan strateji ve tekniklere ilişkin görüşleri tablo $13^{\prime}$ de sunulmuştur. 
Tablo 13. Öğretmenlerin Programda Öğrenme-Öğretme Sürecinde Yer Alan Strateji ve Tekniklere İlişkin Görüşleri

\begin{tabular}{|c|c|c|c|}
\hline Temalar (Kategoriler) & Kodlar & $\mathrm{n}$ & $\%$ \\
\hline \multirow[b]{2}{*}{ Uygulanabilirlik } & $\begin{array}{l}\text { Uygulanabilir değil (Ö1, Ö2, Ö3, Ö6, Ö9, Ö14, Ö16, Ö17, Ö18, } \\
\text { Ö19) }\end{array}$ & 10 & 52.6 \\
\hline & $\begin{array}{l}\text { Uygulanabilir ancak geliştirilmesi gerekir (Ö4, Ö8, Ö12, Ö13, } \\
\text { Ö15, Ö18) }\end{array}$ & 6 & 31.5 \\
\hline \multirow{9}{*}{$\begin{array}{l}\text { Uygulanan Strateji ve } \\
\text { Teknikler }\end{array}$} & $\begin{array}{l}\text { Kelime ve dilbilgisi etkinlikleri (Ö1, Ö2, Ö3, Ö5, Ö6, Ö9, Ö14, } \\
\text { Ö16, Ö17, Ö18, Ö19) }\end{array}$ & 11 & 57.8 \\
\hline & Drama/Rol Yapma (Ö1, Ö7, Ö8, Ö9, Ö11, Ö12, Ö15, Ö17, Ö19) & 9 & 47.3 \\
\hline & Diyalog Oluşturma (Ö4, Ö13, Ö15) & 3 & 15.7 \\
\hline & Oyunlar (Ö4, Ö8) & 2 & 10.5 \\
\hline & Anlam Haritaları (Ö11, Ö12) & 2 & 10.5 \\
\hline & Tahmin etme aktiviteleri $(O ̈ 4, O ̈ 8)$ & 2 & 10.5 \\
\hline & Kinestetik aktiviteler (Ö18, Ö16) & 2 & 10.5 \\
\hline & Şarkılar, video $(O ̈ 8, O ̈ 16)$ & 2 & 10.5 \\
\hline & Soru-cevap etkinlikleri (Ö4) & 1 & 5.3 \\
\hline
\end{tabular}

Tablo 13 incelendiğinde programda öğrenmeöğretme sürecinde yer alan strateji ve tekniklerle ilgili öğretmenlerin görüşleri "uygulanabilirlik" ve "uygulanan strateji ve teknikler" temaları çerçevesinde ifade edilmiştir. Strateji ve tekniklerin uygulanabilirliği konusunda öğretmenler \%52.6 oranında strateji ve tekniklerin uygulanabilir olmadığını ileri sürmüştür. Öğretmenlerin görüşlerinden bazıları aşağıda yer almaktadir.

"Programda yer alan strateji ve tekniklerin gerçeği yansıtmadığımı ve sinıfta uygulanabilir olmadığımı düşünüyorum. Kelime ve dilbilgisi aktiviteleri yapıyorum." (Ö2)

"Bence yöntemler uygulanabilir değil çünkü hiç gerçekçi değil. Ben derste dilbilgisi aktiviteleri, kelime çalışmaları, kinestetik aktiviteler yaptırmaya çalışıyorum ve videoyu kullanıyorum." (Ö16)

\%31.5 oranında ise strateji ve tekniklerin uygulanabilir ancak geliştirilmesi gerektiği öğretmenler tarafından aşağıdaki gibi ifade edilmiştir.

"Programdaki stratejilerin uygulanabilir olduğunu düşünüyorum ama bence daha da geliştirilmesi gerekiyor." (Ö8)
"Yöntemleri uygulamaya çalışıyorum ama bu sinıf şartlarında yöntemler daha da geliştirilmeli ve daha iyi hale getirilmeli." (Ö13)

“Yöntemler uygulanabilir gibi gözüküyor. İletişimi geliştirmek üzerine kurulmuş olan programda yöntemlerin ve aktivitelerin gerçekçi bir ortamda yapulabilmesi için üzerinde biraz daha çalışılması gerekir bence." (Ö19)

Öğretmenlerin uyguladıkları strateji ve teknikler açısından görüşleri en çok \%57.8 oranında kelime ve dilbilgisi etkinlikleri şeklindedir. Diğer görüşler sırasıyla \%47.3 oranında dra$\mathrm{ma} /$ rol yapma, \%15.7 oranında diyalog oluşturma, \%10.5 oranında oyunlar, anlam haritaları, tahmin etme aktiviteleri, kinestetik aktiviteler, şarkılar, video ve \%5.3 oranında ise sorucevap etkinlikleri şeklindedir. Öğretmenlerin görüşlerinden alınan birebir alıntılar aşağıda sunulmaktadır.

"Ben sinıfta drama yöntemini kullanyorum. Ayruca, oyunlar oynatıyorum, şarkılar dinletiyorum. Öğrencilere tahmin etme aktiviteleri yaptırıyorum." (Ö8)

"Sınıfta diyalog oluşturmayı kullanabiliyorum." (Ö13) 
"Sinifta rol oynama, drama, klasik dilbilgisi ve kelime çalışmaları yapıyoruz." (Ö19)
Öğretmenlerin programda öngörülen değerlendirme yöntemlerine yönelik görüşleri tablo 14 'de sunulmuştur.

Tablo 14. Öğretmenlerin Programda Öngörülen Değerlendirme Yöntemlerine Yönelik Görüşleri

\begin{tabular}{|c|c|c|c|}
\hline Temalar (Kategoriler) & Kodlar & $\mathrm{n}$ & $\%$ \\
\hline \multirow[t]{2}{*}{ Önem } & $\begin{array}{l}\text { Yöntemler dil öğretimi için gerekli (Ö1, Ö3, Ö4, Ö5, Ö6, Ö7, Ö8, } \\
\text { Ö10, Ö13, Ö15, Ö16, Ö17, Ö19) }\end{array}$ & 13 & 68.4 \\
\hline & Yöntemler dil öğretimi için uygulanmalı (Ö2, Ö5) & 2 & 10.5 \\
\hline Uygulanma durumu & $\begin{array}{l}\text { Yöntemler uygulanmiyor (Ö1, Ö3, Ö4, Ö6, Ö7, Ö8, Ö9, Ö10, } \\
\text { Ö11, Ö12, Ö13, Ö14, Ö15, Ö16, Ö18, Ö19) }\end{array}$ & 16 & 84.2 \\
\hline \multirow{4}{*}{$\begin{array}{l}\text { Uygulanmama } \\
\text { denleri }\end{array}$} & Öğrenci seviyesine uygun değil (Ö3, Ö4, Ö6, Ö7, Ö8, Ö11, Ö12) & 7 & 36.8 \\
\hline & Zaman sıkıntısı var (Ö7) & 1 & 5.3 \\
\hline & Öğrenciler objektif olamiyor (Ö8, Ö13, Ö16, Ö19) & 4 & 21.05 \\
\hline & Bölgeden kaynaklı sıkıntılar var (Ö15, Ö17) & 2 & 10.5 \\
\hline
\end{tabular}

Tablo 14 incelendiğinde programda öngörülen değerlendirme yöntemlerine ilişkin öğretmenlerin görüşleri “önem”, "uygulanma durumu” ve "uygulanmama nedenleri" temaları çerçevesinde ifade edilmiştir. Değerlendirme yöntemlerinin önemine yönelik öğretmenlerin görüşleri \%68.4 oranında yöntemler dil öğretimi için gerekli ve \%10.5 oranında yöntemler uygulanmalı şeklindedir. Bununla ilgili bazı görüşler;

"Değerlendirme yöntemleri dil ă̆ırlı̆̆ı açısından çok gerekli." (Ö5)

"Yöntemlerin dil öğretimi için uygulanmasımın doğru olduğunu düşünüyorum." (Ö15) şeklindedir.

Değerlendirme yöntemlerinin uygulanma durumuna yönelik öğretmenler tarafından \%84.2 oranında yöntemlerin uygulanmadığı belirtilmiştir. Bununla ilgili bazı görüşler;

"Akran değgerlendirme, portfolyo yöntemlerinin dil öğretimi için gerekli olduğunu düşünüyorum ancak öğrencilerin seviyelerine uygun olmadı ğ $ı$ için yöntemleri uygulamıyorum." (Ö6)

"Portfolyo, akran değerlendirme yapılmıyor ama yapılması gerektiğini düşünüyorum. Öğrencilerin kendi değerlendirmelerini objektif bulmuyorum." (Ö13) şeklindedir.

Öğretmenlerin değerlendirme yöntemlerinin uygulanmama nedenlerine ilişkin görüşleri en çok \%36.8 oranında yöntemlerin öğrenci seviyesine uygun olmadiğı yönündedir. Diğer görüşler sırasıyla \%21.05 oranında yöntemlerin uygulanmasında öğrencilerin objektif olamadıkları, \%10.5 oranında bölgeden kaynaklı sıkıntıların yaşandığı ve \%5.3 oranında zaman sıkıntısının yaşandığı şeklindedir. Öğretmenlerin görüşlerinden alınan alıntılar aşağıda verilmiştir.

“Öz değgerlendirme ve akran değgerlendirme yapılmıyor. Zaman sıkıntısı öğrenci grubu yaşının küçük olması olumsuz etkiliyor. Hâlbuki bütün değgerlendirme teknikleri önemli ve yapulmalı." (Ö7)

"Öz ve akran değgerlendirmenin uygulanamayacağını düşünüyorum. Öğrencilerin seviyelerine uygun olmadığını düşünüyorum." (Ö11)

“...̈z akran değerlendirme ile portfolyo yapamıyorum. Bölgeden kaynakl sebepler bunu etkiliyor." (Ö15)

“Öz-akran değerlendirme ve portfolyo yaptırmıyorum. Fakat dil öğrenimi için bu dört temel değerlen- 
dirme yönteminin yararl ve gerekli olduğunu görüyorum. Sadece bizim öğrencilerimiz kendilerini ve akranlarını yansız bir şekilde değerlendiremezler." (Ö19)
Öğretmenlerin programın uygulanmasında karşılaşılan problemler ve bu problemlere yönelik kendi çözüm önerilerine ilişkin görüşleri tablo $15^{\prime}$ de sunulmuştur.

Tablo 15.Öğretmenlerin Programın Uygulanmasındaki Problemlere ve Bu Problemlere Yönelik Çözüm Önerilerine İlişkin Görüşleri

\begin{tabular}{|c|c|c|c|c|}
\hline $\begin{array}{l}\text { Tema (Kategori- } \\
\text { ler) }\end{array}$ & \multicolumn{2}{|l|}{ Kodlar } & $\mathrm{n}$ & $\%$ \\
\hline & \multicolumn{2}{|c|}{$\begin{array}{l}\text { Zaman yetmiyor (Ö1, Ö2, Ö3, Ö5, Ö6, Ö7, Ö8, Ö9, Ö11, Ö14, Ö15, } \\
\text { Ö18, Ö19) }\end{array}$} & 13 & 68.4 \\
\hline & \multicolumn{2}{|c|}{$\begin{array}{l}\text { Ders kitab1 programin uygulanmas1 için uygun değil (Ö4, Ö6, Ö7, Ö8, } \\
\text { Ö9, Ö11, Ö15, Ö16) }\end{array}$} & 8 & 42.1 \\
\hline Problemler & \multicolumn{2}{|c|}{ Öğrenci seviyesi program için düşük (Ö7, Ö10, Ö11, Ö12, Ö14, Ö18) } & 6 & 31.5 \\
\hline & \multicolumn{2}{|c|}{ Yeterli etkinlik yok (Ö13, Ö14, Ö16) } & 3 & 15.7 \\
\hline & \multicolumn{2}{|l|}{ Etkinlikler ilgi çekici değil (Ö4) } & 1 & 5.3 \\
\hline & \multicolumn{2}{|c|}{ Kültürümüze uygun olmayan konular ve ifadeler var (Ö4) } & 1 & 5.3 \\
\hline & \multicolumn{2}{|l|}{ Sinıf mevcudu fazla (Ö9) } & 1 & 5.3 \\
\hline & \multicolumn{2}{|c|}{$\begin{array}{l}\text { Haftalık ders saatleri attırılmalı (Ö1, Ö2, Ö3, Ö4, Ö5, Ö6, Ö8, Ö9, Ö15, } \\
\text { Ö16, Ö18, Ö19) }\end{array}$} & 12 & 63.1 \\
\hline & \multicolumn{2}{|c|}{$\begin{array}{l}\text { Ders kitab1 değişmeli/revize edilmeli (Ö2, Ö4, Ö6, Ö8, Ö9, Ö11, Ö14, } \\
\text { Ö15, Ö16, Ö18) }\end{array}$} & 10 & 52.6 \\
\hline & \multicolumn{2}{|c|}{ İçerik görsellerle zenginleştirilmeli (Ö3, Ö4, Ö13, Ö16, Ö18) } & 5 & 26.3 \\
\hline & \multicolumn{2}{|c|}{ Etkinlikler çoğaltılmalı (Ö8, Ö9, Ö10, Ö12, Ö13) } & 5 & 26.3 \\
\hline Çözüm önerileri & \multicolumn{2}{|c|}{ İçerik günlük hayatla ilişkilendirilmeli (Ö5, Ö14, Ö16) } & 3 & 15.7 \\
\hline & \multicolumn{2}{|c|}{ Program daha eğlenceli bir hale getirilmeli (Ö2, Ö3, Ö7, Ö18) } & 4 & 21.05 \\
\hline & \multicolumn{2}{|c|}{ Dört temel beceri programda eşit olarak yer almalı (Ö6, Ö15) } & 2 & 10.5 \\
\hline & \multicolumn{2}{|c|}{ Konu yoğunluğu azaltılmalı (Ö10, Ö17) } & 2 & 10.5 \\
\hline & \multicolumn{2}{|c|}{ Materyallere ulaşım kolaylığı sağlanmalı (Ö7, Ö16) } & 2 & 10.5 \\
\hline & \multicolumn{2}{|l|}{ Seviye sınıfları oluşturulmalı } & 1 & 5.3 \\
\hline \multirow{3}{*}{\multicolumn{2}{|c|}{$\begin{array}{l}\text { Tablo } 15 \text { incelendiğinde öğretmenlerin görüşle- } \\
\text { ri "problemler" ve “çözüm önerileri” temaları } \\
\text { çerçevesinde ifade edilmiştir. Programın uygu- } \\
\text { lanmasında yaşanılan problemlere yönelik } \\
\text { öğretmenlerin görüşleri en çok \%68.4 oranında } \\
\text { zamanın yetmemesi şeklindedir. Bununla ilgili } \\
\text { bazı görüşler; }\end{array}$}} & \multirow{2}{*}{\multicolumn{3}{|c|}{$\begin{array}{l}\text { "Programın uygulanması için zaman kesinlikle } \\
\text { yeterli değil." (Ö3) şeklindedir. }\end{array}$}} \\
\hline & & & & \\
\hline & & \multirow{5}{*}{\multicolumn{3}{|c|}{$\begin{array}{l}\text { Diğer görüşler sırasıyla \%42.1 oranında ders } \\
\text { kitabı programın uygulanması için uygun } \\
\text { değil, \%31.5 oranında öğrenci seviyesi program } \\
\text { için düşük, \%15.7 oranında programda yeterli } \\
\text { etkinlik yok, \%5.3 oranında etkinlikler ilgi } \\
\text { çekici değil, kültürümüze uygun olmayan } \\
\text { konular ve ifadeler var, sınıf mevcudu fazla } \\
\text { şeklindedir. Bununla ilgili görüşler aşağıda } \\
\text { sunulmaktadır. }\end{array}$}} \\
\hline \multirow{5}{*}{\multicolumn{2}{|c|}{$\begin{array}{l}\text { "Programın uygulanmasında özellikle ders saatinin } \\
\text { az olmasını eleştiriyorum. 5. ve 6. Sınıflarda } 3 \text { saat } \\
\text { ders saatinin yeterli olmadığını düşünüyorum. Pek } \\
\text { çok beceri eksik kalıyor. Bunun tek çözümü de ders } \\
\text { saatinin artırılması olabilir." (Ö2) }\end{array}$}} & & & \\
\hline & & & & \\
\hline & & & & \\
\hline & & & & \\
\hline & & $\begin{array}{l}\text { "Programda çocuğun ilgisini to } \\
\text { yok. Programda yazılanlarla uygı }\end{array}$ & & $\begin{array}{l}\text { inlikler } \\
\text { oluyor }\end{array}$ \\
\hline
\end{tabular}


çünkü hazırlanan ders kitabı bu kazanımları ve gereklilikleri karşılar nitelikte değil. Amaçlananla sunulan arasında çok büyük fark var. Kültüre uygun olmayan ifadeler ve konular olduğunu düşünüyorum." (Ö4)

"Program öğrenci seviyesine uygun değil, yoğunluk fazla..." (Ö10)

"Program uygulamak için öğrenci seviyesi düşük ve zaman yetersiz. Programda etkinlikler az." (Ö14)

“Öğrenci seviyesinin üstünde olan bir program olmasından kaynaklı problemler yaşıyoruz." (Ö18)

Yaşanılan problemlere yönelik öğretmenlerin çözüm önerileri en çok \%63.1 oranında haftalık ders saatleri arttırılmalı şeklindedir. Diğer öneriler sırasıyla \%52.6 oranında ders kitabı değişmeli/revize edilmeli, \%26.3 oranında içerik görsellerle zenginleştirilmeli ve etkinlikler çoğaltılmalı, \%21.05 oranında program daha eğlenceli bir hale getirilmeli, \%15.7 oranında içerik günlük hayatla ilişkilendirilmeli, \%10.5 oranında dört temel beceri programda eşit olarak yer almalı, konu yoğunluğu azaltılmalı ve materyallere ulaşım kolaylığı sağlanmalı, $\% 5.3$ oranında seviye sınıfları oluşturulmalı şeklindedir. Öğretmenlerin görüşlerinden alınan birebir alıntılar aşağıda sunulmaktadır.

"Aynı zamanda kitapların da değişmesi gerekiyor ve programın öğrenci ve öğretmen için daha eğlenceli ve uygulanabilir hale getirilmesi gerekiyor." (Ö2)
"Ders saati artırılmall, kitap değiştirilmeli seviye sınıfları oluşturulmalı çünkü Ingilizce bir beceri dersidir. Görsellerle ders zenginleştirilmeli ve eğlenceli hale getirilmeli." (Ö3)

"Ders saati artırılmall, öğrencilerin hazırbulunuşluğuna, ilgisine uygun ve görsel olarak kitap değişmeli. Programı uygulamak mümkün olmuyor bu yüzden kitap tamamen değişmelidir." (Ö4)

“...programın yükü azaltılmalı ve etkinlikler arttırtlarak her seviyeye uygun her öğrencinin yapabileceği türden seçilmeli." (Ö10)

"Program günlük hayatla daha iç içe olmall, konular uygun seçilmeli. Kitap revize edilmeli ve programa uyumu să̆lanmalı." (Ö14)

"Ders saatlerinin arttırılması gerekiyor. Başka türlü programı yetiştirmek mümkün olmuyor. Öğrenciye Ingilizceyi sevdirmenin yolu olan şarkılara ve hikayelere yer vermek mümkün olmuyor. Ders saatinin arttırılması gerekir. Ders kitabının da değiştirilmesi gerekir. Ayrıca, bence içeriğin görsel olarak daha renkli olması gerekir. Ĕglenceli hale getirilen Ingilizce dersinin Ingilizceye olan ön yargıyı da sileceğini düşünüyorum." (Ö18)

Programla birlikte değişen ders kitapları ve ders materyallerine yönelik öğretmenlerin görüşleri tablo $16^{\prime}$ da sunulmuştur.

Tablo 16.Öğretmenlerin Programla Birlikte Değişen Ders Kitapları ve Ders Materyallerine İlişkin Görüşleri

\begin{tabular}{llcc}
\hline $\begin{array}{l}\text { Temalar (Kategori- } \\
\text { ler) }\end{array}$ & Kodlar & $\mathrm{n}$ & $\%$ \\
\hline \multirow{3}{*}{ Kuvvetli yönler } & Kitap eğlenceli ve sıkıcı değil (Ö1, Ö5) & 2 & 10.5 \\
& Kelimeler ve okuma parçaları öğrenci seviyesine uygun (Ö5, Ö12) & 2 & 10.5 \\
& Kitap öğretmenlere bir rehber niteliğinde (Ö19) & 1 & 5.3 \\
\hline \multirow{5}{*}{ Zayıf Yönler } & İcrerik zayıf (Ö2, Ö3, Ö6, Ö8, Ö12, Ö13, Ö14, Ö16) & 8 & 42.1 \\
& Etkinlikler çok az (Ö3, Ö4, Ö7, Ö8, Ö9, Ö13, Ö16, Ö18) & 8 & 42.1 \\
& Kitapla birlikte verilmesi gereken materyaller (dinleme CD’leri) & 4 & 21.05 \\
& yok (Ö11, Ö15, Ö16, Ö18) & 3 & 15.7 \\
& Kitap programı yanstmiyor (Ö6, Ö11, Ö14) & 3 & 15.7 \\
\hline & Kilavuz kitap öğretmenleri yönlendirmiyor (Ö6, Ö11, Ö14) & & \\
\cline { 2 - 3 } &
\end{tabular}




\begin{tabular}{lcc}
\hline Beceriler eksik (Ö2, Ö8) & 2 & 10.5 \\
Gereksiz ve bilinmeyen kelimeler fazla (Ö4, Ö17) & 2 & 10.5 \\
Konu dağılımı ve sırası kötü (Ö4, Ö17) & 2 & 10.5 \\
Yoğunluk fazla (Ö1, Ö10, Ö17) & 3 & 15.7 \\
Hatalar var (Ö4) & 1 & 5.3 \\
İçerik ilgi çekici değil (Ö17) & 1 & 5.3 \\
Seviyeye uygun değil (Ö18) & 1 & 5.3 \\
Kitap görsel açıdan kötü (Ö17) & 1 & 5.3 \\
\hline
\end{tabular}

Tablo 16 incelendiğinde öğretmenlerin programla birlikte değişen ders kitapları ve ders materyallerine ilişkin görüşleri "kuvvetli yönler" ve "zayıf yönler" olmak üzere iki tema çerçevesinde ele alınmıştır. Kuvvetli yönlere ilişkin öğretmenlerin görüşleri en çok \%10.5 oranında kitap eğlenceli ve sıkıcı değil ile kelimeler ve okuma parçaları öğrenci seviyesine uygun şeklindedir. Diğer görüş ise \%5.3 oranında kitap öğretmenlere bir rehber niteliğinde şeklindedir. Ders kitabına ilişkin bir öğretmenin olumlu görüşü aşağıda verilmiştir.

"Ders kitabın beğeniyorum. Kelimeler ve okuma metinlerinin seviyeye uygun olduğunu düşünüyorum. Bilgi yoğunluğunun olması çocukları sıkar fakat kitabın bundan uzak olduğunu düşünüyorum." (Ö5)

Zayıf yönlere ilişkin öğretmenlerin görüşleri en çok \%42.1 oranında içerik zayıf ve etkinlikler çok az şeklindedir. Diğer görüşler sırasıyla $\% 21.05$ oranında kitapla birlikte verilmesi gereken materyaller (dinleme CD'leri) yok, \%15.7 oranında kitap programı yansıtmıyor, kılavuz kitap öğretmenleri yönlendirmiyor ve yoğunluk fazla, \%10.5 oranında beceriler eksik, gereksiz ve bilinmeyen kelimeler fazla ile konu dağılımı ve sırası kötü, \%5.3 oranında hatalar var, içerik ilgi çekici değil, seviyeye uygun değil ve kitap görsel açıdan kötü şeklindedir. Öğretmenlerin olumsuz görüşlerinden alınan birebir alıntılar aşağıda sunulmaktadır.

"5.sinıf kitabı geçen yılkine göre daha boş olduğunu düşünüyorum. Geçen yılki kitap içerik açısından oldukça boş, öğrencilere aktarılması gereken beceri- ler eksik. Bu eksiklikleri tamamlamak içinde ek kaynak kullanmak gerekiyor. Çalışma kağıtların hazırlamak gerekiyor." (Ö2)

“Ders kitabının programı yansıtacak düzeyde hazırlanmadığını düşünüyorum. Okuma ve yazmaya daha çok yer verilmesi gerektiğini düşünüyorum. Kılavuz kitabın yetersiz olduğunu düşünüyorum. Kitapta bizi yönlendirecek extra çalışmalara yer verilmemiş. Dinleme CD'lerini olmaması da bizim için dönem başında problem olmuştur. Kendi çabalarımızla dinleme çalışmalarını yaptık." (Ö11)

"Görsel açıdan kitaplar çok kötü. Ünite stralamastnın da yanlıs olduğunu düşünüyorum. Present Simple ile giriş yapılmış. Hello ünitesi ise 3. veya 4. ünite. Parçalarda çok fazla bilinmeyen kelime var. Konu olarak da ilgi çekici değiller. 11-12 yaş çocuğunun Simpsons veya mekik-şınava ilgi duyuyor olması ütopik. Ünite sayısı azaltılmış ancak konular diğer ünitelere yedirilmiş. Ders saati de azalinca yetmiyor." (Ö17)

“Ders kitaplar 10 üniteye düşmüş olsa bile içeriğin hiç değişmediğini düşünüyorum. Seviyeye uygun olmayan, altyapı çalışması yapılmamış bir program olduğunu düşünüyorum. Kitaptaki etkinlikler çok yetersiz, etkinlikler arttırlmall. Ayrica bize dil öğretimi ile ilgili extra kaynak sağlanmıyor. Materyalleri tamamen kendimiz hazırlyoruz." (Ö18)

\section{SONUÇ, TARTIŞMA ve ÖNERILLER}

Araştırmada yeni 5. sınıf İngilizce dersi öğretim programı ile bir önceki 5. sınıf İngilizce dersi öğretim programının karşılaştırılmalı olarak incelenmesi sonucunda bir önceki programdan 
farklı olarak yeni programda yapılan yenilikler şu şekilde özetlenmiştir: İngilizce öğrenme yaşı düşürülmüştür. Programın genel amacı, İngilizcenin öğrenciler tarafından gerçek yaşamda kullanılmasıdır. Programda benimsenen yaklaşım, iletişim için gerçek öğrenme ortamlarının oluşturulmasıdır. Öğretim teknik ve ders materyallerine ek olarak öğrenci anlatımı, resimler, posterler, gerçek yaşamdan (authentic) materyaller ve çizme etkinlikleri önerilmiştir. Değerlendirme tekniklerine ek olarak akran değerlendirme, dinleme ve konuşma becerilerini de ölçen kalem-kağıt sınavları önerilmiştir. Ünite sayısı azaltılmış ancak içerik yoğunluğu değişmemiştir. Avrupa Ortak Dil Çerçeve Programı dil seviyelerine göre beceriler hedefler belirlenmiş, beceri kazanım sayıları azaltılmış ve yazma becerileri çıkartılmıştır. Dil işlevleri (functions) sayısı arttırılmıştır.

2013 programı ile birlikte İngilizce öğrenme yaşının düşürülmesi olumlu bir adım olarak düşünülebilir. Bireylerin yeni bir dili kolay öğrenebilmeleri açısından dil öğretimine erken yaşta başlanılmalıdır (Sevinç, 2003). Yabancı dil öğretimi alanında pek çok uzmanın da belirttiği gibi küçük yaşta başlayan yabancı dil öğretimi öğrencilerin konuşma ve telaffuz gibi becerilerinin ileriki yaşlarda daha gelişmiş olmasına katkıda bulunmaktadır. Krashen (1973) erken yaşta dil öğretimi ile ilgili olarak dil gelişiminin iki yaşında başladığını ve ergenlik dönemine kadar sürdüğünü belirterek, bu yaşlar aralığında dilin kolaylıkla öğrenilebileceğini ifade etmiştir. Lambert (1972) da yabancı dil öğrenmede kritik döneme vurgu yaparak, bu dönem geçmeden başlanan yabancı dil eğitiminin ileriki yaşamında çocuğa olumlu etkileri olacağını savunmuştur. Ayrıca Kara (1999)' ya göre, erken yaşta dil öğretimine başlanılması ile bireylerin bireysel ve kültürel gelişimlerine de katkı sağlanmaktadır. Böylece ikinci sınıfta başlayan İngilizce öğretiminin çocuğun sadece dil gelişimine değil hayatının pek çok alanında fayda sağlayacağı düşünülebilir.

2013 programında öğrenciler tarafından güncel yaşamda İngilizcenin kullanılmasının amaçlanması ve öğrenme-öğretme sürecinde öğrencilerin ilgisini çekebilecek farklı materyal ve etkinliklerin önerilmesinin programın uygulanması açısından olumlu bir gelişme olduğu söylenebilir. Cihan ve Gürlen (2013) tarafından yapılan araştırmada öğretmenlerin görüşlerine göre 2006 programında yer alan üniteler gerçek yaşamla bağlantı kurmayı amaçlasa da, öğrenciler uygulamada öğrendiklerini kullanamadıklarında bilgilerini unutmaktadırlar sonucuna ulaşılmıştır. Benzer şekilde Er (2006) tarafından yapılan araştırmada 2006 yılı 5. sınıf İngilizce dersi öğretim programına yönelik öğretmen ve müfettişlerin görüşleri alınmıştır. Araştırmanın sonuçlarına göre içeriğin öğrenciler açısından eğlenceli olmadığı ve öğrencileri gerçek yaşamda İngilizce konuşmaya cesaretlendirici nitelikte olmadığı belirlenmiştir. 2013 programinda bu yönde yapılan değişikliklerle programın bir önceki program için belirtilen zayıf yönlerinin geliştirildiği söylenebilir.

Araştırmada yeni programa yönelik öğretmen görüşlerinin incelenmesi ile elde edilen sonuçlar şu şekildedir: Öğretmenlerin programla ilgili olumsuz görüşleri fazladır. Görüşme yapılan öğretmenlerin çoğuna programla ilgili bilgilendirme yapılmamıştır. Okuma, konuşma ve dinleme becerileri öğrenci seviyesinin üstündedir. Ayrıca, yazma becerilerine yönelik kazanımların olmaması büyük eksikliktir. Çoğunlukla öğrenme ve öğretme süreçleri uygulanabilir değildir. En çok kelime ve dilbilgisi etkinlikleri tercih edilmektedir. Öngörülen değerlendirme yöntemleri dil öğretimi için gerekli fakat uygulanmamaktadır. Programın uygulanmasında en çok yaşanılan sıkıntılar ders saatinin yetersiz olması ve ders kitabının programa uygun olmamasıdır. Öğretmenlerin 
çözüm önerilerinin başında ders saatlerinin arttırılması ve ders kitaplarının revize edilmesi yer almaktadir.

2006 yılı 5. sınıf İngilizce dersi öğretim programı ile ilgili yapılan araştırmalarda da yeni programla ilgili öğretmenlere bilgilendirme yapılmadığından dolayı programın uygulanmasında öğretmenlerin sorunlar yaşadıkları tespit edilmiştir (Cihan ve Gürlen, 2013; ZehirTopkaya ve Küçük, 2010). Öğretmenlerin yeni uygulamaya başlayacağı bir öğretim programı hakkında daha önceden herhangi bir mesleki çalışma veya hazırlık yapılmaması halinde başarıya ulaşması muhtemel olabilecek programın etkililik oranını düşüreceği düşünülmektedir. Bu nedenle 2013 programı için de öğretmenlere yeterince bilgilendirme çalışmalarının yapılmaması benzer sorunların yaşanmasına neden olabilir.

Bununla birlikte 2006 programinda da okuma, yazma, konuşma ve dinleme becerilerinin gerçekleştirilmesinde öğretmenlerin sorunlar yaşadıkları tespit edilmiştir (Cihan ve Gürlen, 2013; Büyükduman, 2005). 2013 programinda da dil becerileri ile ilgili revize çalışmaları yapılmış olmasına rağmen öğretmenlerin bu sıkıntılarının devam ettiği söylenebilir. Kalıcı bir yabancı dil öğrenimi için dilin dört temel becerisi de eşit oranda geliştirilmelidir. Becerilerin biri ya da birkaçında yaşanacak eksiklik, yabancı dilin etkili öğrenilmesini engellemiş olacaktır. Bu nedenle öğretim sürecinde yabanc1 dil becerilerinin geliştirilmesine özellikle önem verilmelidir. 2006 programı için öğrenme-öğretme sürecinde etkinliklerin uygulanmasında problemler olduğu (Er, 2006; Cihan ve Gürlen, 2013; Büyükduman, 2005; Zehir-
Topkaya ve Küçük, 2010) belirlenmiştir. Aynı şekilde 2013 programında da öğretmenlerin çoğunluğu öğrenme-öğretme süreçlerinin uygulanabilir olmadığı yönünde görüş bildirmiştir. 2013 programı için değerlendirme yöntemlerinin gerekli olduğu ancak sınıfta uygulanamadığı bildirilmiştir. Bu sonuca paralel olarak 2006 yılı programının değerlendirme yöntemlerine yönelik ölçme ve değerlendirme örneklerinin yeterli olmadığı (Er, 2006; Cihan ve Gürlen, 2013) ve bu nedenle öğretmenlerin uygulamada zorluklar yaşadıkları (Cihan ve Gürlen, 2013) belirtilmiştir. Bununla birlikte yapılan araştırmalarda öğretmenlerin zaman sıkıntısı çektikleri (Er, 2006; Cihan ve Gürlen, 2013; Büyükduman, 2005) belirlenmiş ve 2006 programına yönelik öğretmenler tarafından içerik yoğunluğuna dikkat çekilmiştir (ZehirTopkaya ve Küçük, 2010). 2013 İngilizce dersi öğretim programının uygulanmasında da öğretmenlerin zaman sıkıntısı yaşamaları, yeni programda ünite sayısı azaltılsa bile içerik yoğunluğunun aynı kalmasından kaynaklanabilir. Bu bağlamda 2013 programında içerik yoğunluğunun azaltılmasına yönelik bir revize yapılmadığı söylenebilir. Ayrıca, mevcut araştırmada ögrretmenler tarafından ders kitabının programa uygun olmadığı ifade edilmiştir. Benzer olarak yapılan araştırmalarda da 2006 programı için ders kitaplarının program amaçlarıyla tutarlı olmaması ve kitaplardaki örneklerin yetersiz olması (Büyükduman, 2005) ile ders kitaplarının uygun olmadığı (ZehirTopkaya ve Küçük, 2010) sonuçlarına ulaşılmıştır. Programlar revize edildiğinde ders kitaplarının yeni programa uygun olarak revize edilmesi gerektiği ihtiyacı hissedilmektedir. 


\section{Kaynakça}

Büyükyavuz, O. ve Aydoslu, A. (2005) Burdur'da İngilizce öğretmenlerinin karşılaştığı sorunlar, 1. Burdur Sempozyumu (16-19 Kastm), Mehmet Akif Ersoy Üniversitesi, Burdur.

Büyükduman, F. İ. (2005). İlköğretim okulları İngilizce öğretmenlerinin birinci kademe İngilizce öğretim programına ilişkin görüşleri. Hacettepe Üniversitesi Ĕ̆itim Fakültesi Dergisi, 28, 55-64.

Cihan, T. ve Gürlen, E. (2013). İlköğretim 5. sınıf İngilizce dersi öğretim programına ilişkin öğretmen görüşleri. Anadolu Üniversitesi Sosyal Bilimler Dergisi, 13 (1), 131-146.

Ellis, R. (1990). Instructed second language acquisition. London: Basil Blackwell.

Er, K. E. (2006). Evaluation of english curricula in 4th and 5th grade primary schools. Ankara University Journal of Faculty of Educational Sciences, 39 (2), 1-25.

Işık, A. (2008). Yabancı dil eğitimimizdeki yanlışlıklar nereden kaynaklanıyor?. Journal of Language and Linguistic Studies, 4(2), 15-26.

İlkhan, İ. (1999). Yabancı dil öğretiminin topluma yansımaları. Selçuk Üniversitesi Sosyal Bilimler Dergisi, 5, 301-305.

İşeri, K. (t.y.). Dilin kazanımı ve yabancı dil öğretimi, www.englishclassmersin.com/dilogrenimi/ iseri.pdf adresinden 21 Şubat 2014 tarihinde indirilmiştir.

Kara, Ş. (1999). Erken yaşta yabancı dil öğrenimi ve öğretimi. Dil Dergisi, TÖMER, 79, Ankara Üniversitesi.

Krashen, S. (1973). Lateralization, Language Learning and Critical Period: Some new Evidence. Language Learning, 23, 63-74.

Krashen, S. (2003). Explorations in languaage acquisitionand use. Portsmouth, NH: Heinemann.

Lambert, W. E. (1972). Language, Psychology and Culture. Stanford CA: Stanford University Pres.

Paker, T. (2006). Çal bölgesindeki okullarda İngilizce öğretimini sorunları ve çözüm önerileri. Çal Semроzуити, 1-3 Eylül 2006 (684-690), Denizli.

Richards, J. C. (2001). Curriculum development in language teaching. Cambridge: CUP

Sevinç, M. (2003). Erken çocuklukta gelişim ve eğitimde yeni yaklaşımlar. İstanbul: Morpa Kültür Yayınları.

Songün, R. (1983). Doğu Anadolu orta dereceli okullarda İngilizce öğretmen, öğrencilerinin öğretim, öğrenim ve ilişkileri. Türk Dili Öğrenim Özel Sayısı, 102.

Zehir-Topkaya, E. ve Küçük, Ö. (2010). An evaluation of 4 and 5 grade English language teaching program. Ilköğretim Online, 9 (1), 52-65. [Online]: http://ilkogretim-online.org.tr 


\section{Extended Summary}

The demand for foreign language learning is increasing day by day. English course has become one of the most important lessons according to both students and parents in private and state instutions especially in recent years. From past to present, innovations were made in English teaching together with the changes in education system. Since 1997-1998 academic year, foreign language course has been made compulsory beginning from the fourth grade of primary schools. English language teaching was tried to be built on more modern foundations with English language curriculum prepared in 2006. Today, English language courses start at the second grade because of the changes made with 4+4+4 education system in 2012. In parallel to contemporary approaches and techniques arisen in foreign language education, English language curriculum was revised in 2013. Despite all the studies and innovations made in the field English language teaching, desired results in foreign language learning cannot be achieved neither in primary education nor in secondaryd or higher education. As in the past, diffuculties encountered in language teaching protect their actuality today and various problems related to language teaching are experienced. The importance of the curriculum should also be emphasized among these factors affecting language learning succes negatively in our country. Curricula and practices in teaching processes can be seen as a whole. Because, curricula guides teachers according to which framework plan they continue their teaching-learning activities and what kind of evaluation approach they can use. Considering this function of the curriculum, it is important to prepare a curriculum qualified to train students, able to use foreign language accurately and fluently in our country. Determination of the changes made in the curriculum is considered important in terms of questioning whether the curriculum meets the needs set about English language teaching or not. In addition, determining the opinions of the teachers as curriculum practitioners and firsthand description of the problems encountered in practice are thought to be important in terms of introducing realistic solutions to the problems experienced in teaching English and providing more effective learning experiences.

The aim of this research is to investigate comparatively the new English language curriculum of the fifth grade which started to be applied in 2013-2014 academic year and the English language curriculum of the fifth grade, valid starting from 2008-2009 academic year and to determine teachers' views about new curriculum. The research consists of two stages. At the first stage, the English language curriculum of the fifth grade, started to be applied in 2013, was compared with the English language curriculum of the fifth grade, developed in 2006 and applied in 2008. The new curriculum was named as 2013 curriculum, the previous curriculum was named as 2006 curriculum. Common and different aspects of both curricula were put forth and discussed. At this stage, document analysis method of the qualitative research methods was used and related documents were examined from the fifth grade English language course curricula (2006 curriculum and 2013 curriculum) published on the official website of Ministry of National Education, Board of Education. At the second stage of research, teachers' views about 2013 curriculum were determined. At this stage, the interview method of the qualitative research methods was used and teachers' views were determined with semi-structured interview questions. In this research, in which purposeful sampling was used, interviews were made with 19 English teachers working at the state schools in Sultanbeyli/İstanbul at the second term of 2013-2014 academic year. In the semistructured interview form, there are questions determining general views of the teachers related to the new curriculum, introduction and information given about the new curriculum and the teachers' views about skills targeted to be developed in students within the curriculum, basic activities and strategies 
suggested to be implemented in learning-teaching process, evaluation methods, difficulties/problems experienced in the implementation of the problem and their own solutions to these problems. The obtained data were analyzed with descriptive analysis method and presented in the form of tables.

As a result of comparative examination of the new fifth grade English curriculum and the previous fifth grade English language course curriculum, the innovations in the new curricculum, different from the previous one, were summarized as follows: English learning age was lowered. The overall aim of the curriculum is use of English in real life by students. The approach adopted in the curriculum is the creation of real learning environment for communication. In addition to teaching techniques and course materials, student instruction, pictures, posters, materials from real life(authentic) and drawing activities were proposed. In addition to evaluation techniques, peer evaluation and 'pen and paper' tests measuring listening and speaking skills were suggested. The number of the units was reduced, but the density of the content didn't change. Skills were determined according to the Common European Framework Reference Levels, the number of skill objectives was reduced and writing skills were removed from the the curriculum. The number of the functions was increased. The results obtained by examining the views of the teachers about the new curriculum are the following: There are more negative views of teachers related to the curriculum. Most of the interviewed teachers weren't informed about the curriculum. Reading, speaking and listening skills are above the students' level. Moreover, the absence of writing skills is a great deficiency. Learning and teaching processes are generally not applicable. Vocabulary and grammar activities are preferred the most. Suggested evaluation methods are necessary for language teaching, but they cannot be applied. Most experienced diffuculties in implementing the curriculum are inadequate course hours and coursebooks' inappropriateness for the curriculum. At the beginning of the teachers' suggestions for solutions are increasing the weekly hours of English course and revising the coursebooks. Suggestions below can be presented for the research results: Teachers can be informed about implementation of the new curriculum. Guidance can be provided for problems faced by the teachers in the curriculum application process. Course hours can be made suitable for the curriculum density. Coursebooks can be updated in accordance with the curriculum and the number of the activities in the boks can be increased. 